\title{
THE TRAGEDY OF THE COMMONS AND THE MYTH OF A PRIVATE PROPERTY SOLUTION
}

\author{
AMY SINDEN*
}

According to generally accepted wisdom of welfare economics, there are two potential solutions to the tragedy of the commons: 1) government regulation, or 2) privatization. Government regulation and privatization can usefully be distinguished from each other based on who answers the "how much" question. Under the former, government answers the "how much" question, and under the latter, the market answers it. When the U.S. environmental movement began in the 1970s, government regulation seemed the obvious choice. But in recent years, intellectual fashions have changed, and privatization has become the preferred solution. The privatization solution, however, is a myth that exists, if at all, only in a world of theory. (It is best conceptualized as two distinct solutions: "The private property solution" divides the commons into private parcels such that there are no remaining spillover effects or externalities. "The market solution" eliminates or minimizes transaction costs so that spillover effects will be reduced to optimal levels through Coasian bargaining.) But none of the regimes commonly cited as examples of the privatization solution to the tragedy of the commons actually are. In some instances, the mistake is conceptual. Environmental trading markets and water markets are often mischaracterized as privatization solutions when in fact they rely on government to answer the "how much" question. In other instances, the mistake occurs

* Associate Professor, Temple University, Beasley School of Law. B.A., Swarthmore College, 1984; J.D., University of Pennsylvania, 1991. I wish to thank David Adelman, Jane Baron, Neil Buchanan, Daniel Cole, Joseph Dellapenna, David Driesen, Eric Freyfogle, David Hoffman, Shi-Ling Hsu, Peter Huang, Greg Mandel, and the participants in the working group on Property, Citizenship, and Social Entrepreneurship as well as the participants in the Capstone Colloquium at the University of Florida for helpful comments on earlier drafts. I would also like to thank Temple University and Seattle University School of Law for their generous research support. Last but not least, I would like to thank my father, Frank Sinden-my first and best teacher and unflagging cheerleader-who is fortunately still willing to help me with my math homework. 
in the application of the theoretical concept to the circumstances likely to exist in the real world. Thus, proposed privatization regimes involving land, oceans, and wildlife could conceivably meet the conditions for the private property or market solutions in a theoretical world, but the dynamics of ecological degradation are such that it is impossible for those idealized conditions to be met, or even reasonably approximated, in the real world.

\section{INTRODUCTION}

The central question of environmental policy is "how much?" How much pollution should we release into the ecosystem? How much timber should we cut from the forests? How many fish should we catch from the seas? For some, it might be tempting to answer "none," but that, of course, is impracticable. Human activity could hardly go on without some level of resource exploitation and pollution. Yet, if unchecked, human activity can clearly lead to unacceptable levels of environmental degradation, causing catastrophic and irreversible harms. Somewhere in the middle-between none and too much-is the "right" level of environmental exploitation. For some it is the "optimal" level; for others it is the "efficient" level; for others it is the "sustainable" level. But the central challenge of environmental law is to figure out just where that level is.

For other "how much" questions, our society tends to rely (at least in principle if not in practice) on the free market. How many televisions, iPods, or barbeque grills should we produce? The invisible hand of the free market determines the optimal quantity through the price signals generated by innumerable individual transactions between willing sellers and willing buyers. But when it comes to environmental harms, innumerable externalities cause the magic of the marketplace to fail. Because environmental amenities, like air and water, tend to be open to enjoyment by all, when individuals make decisions that harm these amenities, the costs do not fall entirely on them. Accordingly, under the grim logic of the tragedy of the commons, as each individual pursues her self-interest, these unaccounted-for costs eventually lead to overexploitation of resources and over-production of pollution, to the detriment of 
all. ${ }^{1}$ In short, the market ends up getting the answer to the "how much" question very wrong.

This problem has been well understood for centuries, and according to the received wisdom of neoclassical welfare economics, there are two potential solutions: 1) to intervene in the free market with government regulation; or 2) to privatize the commonly held resource and let the free market work its magic. $^{2}$ In the 1970s, when the American environmental movement was young and our society was optimistic about the ability of government to solve social problems, the first solution seemed like the obvious choice. So Congress set about implementing the government regulation solution through a regime of federal environmental legislation that imposed limits directly on polluters. But almost as soon as the ink was dry on those bold new initiatives, attitudes toward governments and markets began to shift. It's a familiar litany: first the Vietnam War and then Watergate began to slowly eat away at the considerable reserves of idealism and faith in government that had been stockpiled during the previous decades, when the New Deal, victory over fascism in World War II, and the post-war economic expansion had all seemed to testify to the competence and effectiveness of the federal government. Then Reagan declared government the enemy and began to systematically defund and dismantle it. And when the Berlin Wall fell in 1989, the collapse of communism in the Soviet Bloc was read as decisive proof of the superiority of free markets to other forms of social organization.

Accordingly, as we enter the twenty-first century, the intellectual fashions of the day look far different than they did four decades ago when Garrett Hardin wrote his now classic The Tragedy of the Commons and Congress first set about tackling the environmental problem. Government is out; the free market is in. ${ }^{3}$ The Great Society has given way to the Ownership (1968)

1. See Garrett Hardin, The Tragedy of the Commons, 162 SCI. 1243, 1244-45

2. Id. at 1245-46. Common ownership regimes may, under some circumstances, be considered a third solution. See infra notes 40-47 and accompanying text.

3. See Carol M. Rose, The Several Futures of Property: Of Cyberspace and Folk Tales, Emission Trades and Ecosystems, 83 MINN. L. REV. 129, 130 (1998) ("[T] $]$ oday, in the era following the general disillusionment with Marxist economics, property and its close companion, contract, at least in theory have all but swept away command and control as a device for managing resources. .. . Newly invigorated market-oriented economies look to private property solutions for a va- 
Society. Never mind that the program of government intervention this country embarked on in the 1970s seems by nearly all accounts to have been wildly successful, delivering billions of dollars in social benefits at only a fraction of the cost. ${ }^{4}$ To hear even moderate voices tell the tale, one might think we had lived through the gulag - as commentators repeatedly compare this country's "command-and-control" system of environmental regulation to Soviet-style central planning. ${ }^{5}$ The case against government regulation is further bolstered by the now en vogue public choice theory, which, by applying principles of welfare economics to politics, paints a picture of government decision making hopelessly corrupted by special interest influence. ${ }^{6}$

Meanwhile, markets are glorified as the last bastion of truly democratic decision making, where individuals can express their preferences free of interference from big brother government. Through the magic of market exchange, millions of individually expressed preferences lead to a maximization of overall social welfare. The now near hegemonic worldview of

riety of social issues, from fishery management to cyberspace, from air pollution to the dismantling of once forcibly collectivized farms and factories."); see also ERIC T. FREYFogLe, Why CONSERVATION IS FAILING aND HOW IT CAN REGAIN GROUND 40-41 (2006) [hereinafter FREYFOLGE, WHY CONSERVATION IS FAILING] (" $[T]$ he institution of private property ... has risen high in the pantheon of [American] cultural icons since the fall of the Soviet Union.").

4. See OfFICE OF MgMr. \& BUDGET, OFFICE OF INFO. \& REgulatoRy AFFAIRS, VALIDATING REGULATORY ANALYSIS: 2005 REPORT TO CONGRESS ON THE COSTS AND BENEFITS OF FEDERAL REGULATIONS AND UNFUNDED MANDATES ON STATE, LOCAL, AND TRIBAL ENTITIES (Dec. 2005), http://www.whitehouse.gov/omb/ inforeg/2005_cb/final_2005_cb_report.pdf (estimating benefits of federal regulation over past ten years at $\$ 70$ to $\$ 277$ billion and costs at $\$ 35$ to $\$ 39$ billion).

5. See Richard B. Stewart, Controlling Environmental Risks Through Economic Incentives, 13 ColUM. J. ENVTL. L. 153, 154 (1988); see also ClIFFORD S. RUSSELL, APPLYING ECONOMICS TO THE ENVIRONMENT 191 (2001) (noting the "connotational baggage carried by 'command-and-control,' for the phrase harks back to descriptions of the centrally planned economies of Eastern Europe and the Soviet Union"). But see Daniel H. Cole \& Peter Z. Grossman, When is Commandand-Control Efficient? Institutions, Technology, and the Comparative Efficiency of Alternative Regulatory Regimes for Environmental Protection, 1999 WIS. L. REV. 887, 887-88 (1999) ("tak[ing] issue with the general portrayal of command-andcontrol environmental regulations in the economic and legal literature" as comparable to soviet-style central planning and "endemically inefficient and democratically illegitimate").

6. See generally MAXWell L. STEARnS, Public Choice AND Public Law: Readings and Commentary (1997). See also Daniel A. Farber \& Philip P. Frickey, The Jurisprudence of Public Choice, 65 TEX. L. REV. 873, 907-08 (1987) (counseling caution in relying on "[t]he easy generalizations and reductionist models found in the early [public choice] literature[, which] have not fared well empirically"). 
welfare economics helps to rationalize this exaltation of markets, first, by defining optimal social welfare as the state of the world that a perfectly functioning market would achieve, and second, by explaining government intervention as an inevitably flawed, second-best attempt to replicate that market result.

Thus, as academics and policymakers clamor to distance themselves from the now dowdy and stilted fashions of 1970sstyle "command-and-control regulation" and to embrace the virtues of the free market, privatization has replaced government intervention as the preferred solution to the tragedy of the commons. Right wing ideologues pump out books, articles, and monographs touting the virtues of "free-market environmentalism" and claiming that all environmental problems can eventually be solved by simply defining and enforcing private property rights and allowing the free market to function. ${ }^{7}$ But even more moderate voices, who point out the obvious impracticality of privatizing many natural resources, still hurry to agree that privatization is often superior to government regulation and should therefore be pursued wherever practicable. ${ }^{8}$ Thus, extremists and moderates alike tout any environmental policy that looks or smells anything like private property or a market as either an example of the privatization solution or an "intermediate" or "hybrid" scheme that is moving us in that direction. ${ }^{9}$ In this vein, water markets, emissions trading schemes, transferable fishing quotas, and private land owner-

7. See, e.g., TERRY L. ANDERSON \& DONALD R. LEAL, FREE MARKET ENVIRONMENTALISM 27-35 (2001).

8. See, e.g., Daniel H. Cole, Pollution \& Property: Comparing OWnerSHIP INSTITUTIONS FOR ENVIRONMENTAL PROTECTION (2002); Barton H. Thompson, Jr., Tragically Difficult: The Obstacles to Governing the Commons, 30 ENVTL. L. 241, 243-44 (2000). Many authors assume without much analysis that privatization solutions to the tragedy of the commons are at least in some instances practicable. See, e.g., Kristen H. Engel \& Scott R. Saleska, Subglobal Regulation of the Global Commons: The Case of Climate Change, 32 EColoGY L. Q. 183, 191 (2005) (citing proposed carbon dioxide emissions trading schemes as examples of the privatization solution to the tragedy of the commons); Alison Rieser, Prescriptions for the Commons: Environmental Scholarship and the Fishing Quotas Debate, 23 HARV. ENVTL. L. REV. 393, 397 (1999) (referring to "alternatives to government [regulation of environmental problems that] rely [ ] on markets to determine the optimum levels of resource use" and the use of "property rights and market forces to avert the tragedy of the commons").

9. See, e.g., Engel \& Saleska, supra note 8 (citing proposed carbon dioxide emissions trading schemes as examples of the privatization solution to the tragedy of the commons); James E. Krier, Marketable Pollution Allowances, 25 U. TOL. L. REV. 449 (1994); Rose, supra note 3, at 138, 163-69; Richard B. Stewart, Privprop, Regprop, and Beyond, 13 HARV. J.L. \& PUB. POL'Y 91, 93 (1990). 
ship are all touted as examples of the triumph of privatization over the flawed, second-best alternative of government regulation.

In the following pages, I argue that all this talk about private property and market regimes generating an alternative to government regulation of environmental problems is in fact nothing more than a mirage. It has generated a lot of misperceptions about the extent to which government regulation can be dispensed with, and a lot of muddled thinking about exactly what privatization is and under what circumstances it can actually "solve" the tragedy of the commons. In fact, on close inspection, it becomes apparent that simply defining and enforcing private property rights does not necessarily provide a solution. It is only under a very limited and idealized set of circumstances that the delineation of property rights and/or the creation of markets can actually solve the tragedy by aligning private incentives so as to prevent the over-exploitation of resources and the over-production of pollution.

Indeed, it is not clear that this ideal set of conditions is actually met, or even reasonably approximated, in any set of realworld circumstances. Certainly, none of the examples commonly cited as private property or market solutions to environmental problems actually use markets to solve the central problem of the tragedy of the commons. Some, like emissions trading schemes, are simply mischaracterized as privatization solutions, when in fact they continue to use government command to address the central "how much" question of environmental law. Others-like proposals to manage land use, ocean resources, and wildlife solely through private markets-reflect a failure to recognize the extent to which the real-world dynamics of ecological degradation diverge from the idealized conditions necessary for the privatization solution to actually function.

Certainly, many of the more reasonable thinkers on these issues acknowledge that even under so-called private property regimes like emissions trading and individual fishing quotas, government continues to play a crucial role in setting overall "caps" or limits on pollution or fish catch. Still, by treating these schemes-which are essentially forms of government regulation-as if they represent an example of the privatization alternative to government regulation or some intermediate step along the way, these authors lend legitimacy to the claims 
of the free market environmentalists, who-while once widely viewed as a harmless and irrelevant fringe-now have the ear of the president. ${ }^{10}$ What we call things and how we categorize them matters because it influences how we think about them. Particularly as academic ideas get translated into policy through a kind of game of telephone in which pieces get lost at each step of the translation, it is vitally important to be clear and precise in our thinking. At bottom then, this article is a plea for "getting the names right" 11 in our conversations about environmental regulation. In this instance, that means not being afraid to call a government regulation a government regulation.

This article will proceed in three parts. Part I begins by laying out the basic economic theory that has come to under. gird and explain the tragedy of the commons parable. It then considers the two commonly accepted solutions to the tragedy: government regulation and privatization. While these two forms of social organization actually exist on a continuum, they can be usefully differentiated based on who answers the "how much" question. Under the former, government answers the "how much" question, and under the latter, the market answers it. Part I then goes on to explore the "privatization solution," concluding that the concept really conflates two distinct solutions, each of which requires the presence of particularized conditions that will rarely, if ever, exist in the real world. The first, which I call "the private property solution," involves dividing up the commons into parcels of private property in such a way that there are no remaining spillover effects or externalities. In this scenario, the tragedy is solved because each individual owner bears the full costs and benefits of her decisions (externalities are internalized). The second solution, which I call "the market solution," does not require that property boundaries be set so as to eliminate externalities, but does require that transaction costs be eliminated or minimized so that remaining externalities will be reduced to optimal levels through Coasian bargaining.

Parts II and III then examine a series of actual and proposed private property/market regimes that are frequently touted as examples of the privatization solution to the tragedy

10. See infra note 149 and accompanying text.

11. See Joseph W. Dellapenna, The Importance of Getting Names Right: The Myth of Markets for Water, 25 WM. \& MARY ENVTL. L. \& POL'Y REV. 317 (2000). 
of the commons but in fact are not. The programs discussed in Part II (environmental trading markets and water markets) are mischaracterized as privatization solutions because of a conceptual mistake. Because they actually rely on government to answer the "how much" question, they are more appropriately categorized as forms of government regulation. The regimes discussed in Part III (private land ownership, various schemes to privatize ocean resources, and private property rights in fish and wildlife) are mischaracterized as privatization solutions because of what I call an "application mistake." These are privatization solutions in a conceptual sense-that is, there is a set of idealized, hypothetical circumstances under which these regimes could solve the tragedy of the commons. But those circumstances rarely, if ever, exist in the real world. Those who promote these "solutions" fail to account for the dynamics of ecological degradation, which make it impossible to replicate, or even reasonably approximate, the set of circumstances necessary to make these regimes function in practice as either private property or market solutions to the tragedy.

\section{GeTting THE "How MUCH" QUESTION Right: SOLVING THE TRAGEDY OF THE COMMONS}

\section{A. Neoclassical Welfare Economics: The Standard Answer to the "How Much" Question}

In our society, we generally answer "how much" questions through the free market. According to standard neoclassical economic theory, by aggregating individual preferences through innumerable voluntary exchanges, the "invisible hand" of the free market produces economically "efficient" levels of consumer goods and services. Welfare economics-the normative branch of economics ${ }^{12}$-argues that economic efficiency maximizes overall social welfare and should therefore be a goal of social policy.

In its purest form, economic efficiency is defined by the Pareto principle. 13 One state of affairs is a "Pareto improve-

12. See E. J. Mishan, WELFARE ECONOMICS: TEN INTRODUCTORY ESSAYS 1317 (1964).

13. While perfectly competitive markets are Pareto efficient, economists often judge the efficiency of government policies using the more flexible standard of potential Pareto or Kaldor-Hicks efficiency, which asks whether all those who stand 
ment" over another if it would result in at least one person being better off and no one being worse off. A situation is "Pareto optimal" or "Pareto efficient," therefore, if there is no alternative state of affairs that would be a Pareto improvement. ${ }^{14}$

Under the laws of neoclassical economics, Pareto efficiency will be produced by a perfectly competitive market-one in which participants act rationally (consumers maximize utility and producers maximize profits), there are no transaction costs, information is perfect, firms can easily enter and exit the market, goods are homogenous, and all social costs and benefits are accounted for in private costs and benefits (i.e., there are no externalities). ${ }^{15}$ The quantities of consumer goods produced by a free market are determined by innumerable transactions between producers and consumers. In a perfect market, every transaction between a willing seller and a willing buyer produces a Pareto improvement. Since the transaction is voluntary, both buyer and seller are assumed to enjoy an increase in utility. ${ }^{16}$ Moreover, since in a perfect market there are no externalities, all of the costs and benefits associated with the transaction accrue to the two parties, and no one else is made worse off. Thus, under perfect conditions, the market will reach an equilibrium point of Pareto efficiency-that is, a point at which there is no alternative state of affairs that would be a Pareto improvement. ${ }^{17}$

As every freshman economics student learns, this point of equilibrium is reached at the point at which the supply and demand curves cross for a given consumer good or service. ${ }^{18}$ The supply curve graphs the quantity of a good produced as a function of price. It indicates how many bags of potato chips, for example, producers will produce at a given price. The supply curve is primarily a function of production costs. The de-

to benefit from the regulation could fully compensate those who stand to lose from it and still be better off. See AN'THONY E. BOARDMAN ET AL., COST-BENEFIT ANALYSIS: CONCEPTS AND PRACTICES 53 (1996); E.J. MISHAN, COST-BENEFIT ANALYSIS 390 (1976).

14. Gerard Debreu, Valuation Equilibrium and Pareto Optimum, 40 PROC. NAT'L ACAD. SCI. 588, 588 (1954).

15. See Richard CoRnes \& TODd SANDler, THE TheORY OF EXTERnalities, Public Goods, and Club Goods 23 (2d ed. 1996); Paul A. SAMuelson \& WILLIAM D. NORDHAUS, ECONOMICS 158 (17th ed. 2001).

16. See RICHARD A. POSNER, ECONOMIC ANALYSIS OF LAW 11 (2d ed. 1977).

17. See CORNES \& SANDLER, supra note 15, at 23; SAMUELSON, supra note 15, at 158.

18. See SAMUELSON, supra note 15 , at $46-63$. 
mand curve graphs the quantity of a good demanded by consumers as a function of price. Thus, it indicates how many bags of potato chips consumers will demand at any given price. The demand curve is primarily a function of consumers' subjective preferences for the good in question-how much consumers are willing to pay for potato chips. ${ }^{19}$

Neoclassical economic theory demonstrates that a perfect market will reach a Pareto efficient equilibrium at the point at which the supply and demand curves cross. ${ }^{20}$ It further demonstrates that at this point of Pareto equilibrium, the net "utility" or welfare (or level of preference satisfaction) in society as a whole will be maximized. This is because the point at which the supply and demand curves cross is the point at which marginal consumer willingness to pay for potato chips no longer exceeds the marginal costs of production. Up to that point, the production of each additional bag of potato chips provides more benefit in the form of consumer satisfaction than it costs to produce, thus increasing overall social welfare. At this level of potato chip production, both producer profits and consumer satisfaction will be maximized. That is, the net welfare or utility gain to society as a whole from the production and consumption of potato chips will be maximized.21 Thus, a perfect market answers the "how much" question for consumer goods by producing the quantity of each good that maximizes overall social welfare. Economists call this "productive efficiency."

In addition to answering the "how much" question, a perfectly competitive market performs a second function. At a point of Pareto efficient equilibrium, a perfect market not only provides the optimum quantity of any given consumer good (productive efficiency), but it also ensures that the good is optimally distributed among consumers in society (allocative efficiency). ${ }^{22}$ This is because, in a free market, through innumerable voluntary transactions between willing sellers and willing buyers, goods flow to their most valued uses. Potato chips, for example, end up in the hands of those who derive the most utility-or the highest level of preference satisfaction-from their

19. See id. at $47-51$.

20. See id. at $46-63$.

21. See id. at $158-60$.

22. See id. at 158 ("[E]fficiency goes further and requires not only that the right mix of goods be produced but also that these goods be allocated among consumers to maximize consumer satisfactions."); HAL R. VARIAN, INTERMEDIATE MICROECONOMICS: A MODERN APPROACH 301-02 (4th ed. 1996). 
consumption. I use the term "allocative efficiency" or "answering the allocation question" to refer to this second function that markets perform. There is some danger in this, since the term "allocative efficiency" is often used more loosely as a generic term for both kinds of efficiency. But I use the term here in the narrower sense to distinguish the aspect of efficiency that answers the "allocation question" from that aspect of efficiency that answers the "how much" question.

The foregoing analysis employs what economists call a "partial equilibrium analysis." That is, it assumes a single market for a single good. Most law-and-economics scholars employ this approach, ${ }^{23}$ and for my purposes it should generally be adequate. It does, however, represent a considerable simplification of real-world conditions in which multiple markets for multiple goods co-exist and influence each other. Economists have shown through what is called "general equilibrium analysis" that under conditions of perfect competition, multiple interdependent markets operating simultaneously will also reach an equilibrium of both productive and allocative efficiency. ${ }^{24}$ The mathematics necessary to make those showings is, however, quite complex.

Thus, welfare economics equates economic efficiency with the maximization of overall social welfare (or "utility," as it is sometimes called). Social welfare is conceptualized as an aggregate of individual levels of welfare (or "utilities"). Individual welfare is defined in terms of preference satisfaction, and preferences are measured in terms of consumer willingness to pay as expressed in markets. Accordingly, the concept of consumer "willingness to pay" forms the measure of value by which welfare economics gauges overall social welfare. ${ }^{25}$

This use of willingness to pay as the measure of value has come under attack from critics of economic theory and sparked decades of controversy-controversy which remains for the most part unresolved. Critics argue that the concept of willingness to pay artificially forces diverse goods and values into a single monetary metric, ${ }^{26}$ privileges consumer preferences over

23. See, e.g., RICHARD A. POSNER, ECONOMIC ANALYSIS OF LAW 3-21 (6th ed., 2003) (1972).

24. See generally GeRARD DEBREU, The THEORY OF VALUE: AN AXIOMATIC ANALYSIS OF ECONOMIC EQUILIBRIUM (1959); see also VARIAN, supra note 22, at 522-41.

25. See POSNER, supra note 23, at 10.

26. See generally ELIZABETH ANDERSON, VALUE IN ETHICS AND ECONOMICS 
aspirational ideals and values, ${ }^{27}$ privileges the desires of the rich over those of the poor, ${ }^{28}$ fails to acknowledge potential divergences between preferences and actual welfare, ${ }^{29}$ and ignores the extent to which preferences are shaped by existing social conditions, including the legal system itself. ${ }^{30}$ These arguments have much force. Indeed, I have made many of them myself in other contexts. ${ }^{31}$ For the present purposes, however, I am setting these critiques aside and accepting the assumptions of neoclassical economic theory as given. That is to say,

(1993); Jane B. Baron \& Jeffrey L. Dunoff, Against Market Rationality: Moral Critiques of Economic Analysis in Legal Theory, 17 CARDOZo L. REV. 431, 432 (1996); Cass R. Sunstein, Incommensurability and Valuation in Law, 92 MICH. L. REV. 779, 841 (1994); Lawrence H. Tribe, Ways Not to Think About Plastic Trees: New Foundations for Environmental Law, 83 YALE L. J. 1315 (1974). For a particularly thoughtful analysis of the incommensurability problem from a proponent of cost-benefit analysis, see Matthew Adler, Incommensurability and Cost-Benefit Analysis, 146 U. PA. L. REV. 1371 (1998).

27. See Mark Sagoff, THE ECONOMY OF THE EARTH 16-17, 93-94 (1988); ANDERSON, supra note 26, at 192-95, 209-10; ERIC T. FREYFOGLE, THE LAND WE Share: PRIVATE PROPERTy AND THE COMMON GOOD 195-97 (2003) [hereinafter FREYFogle, The LAND WE SHARE].

28. See C. Edwin Baker, The Ideology of the Economic Analysis of Law, 5 PHIL. \& PUB. AFF. 3, 6 (1975); Duncan Kennedy, Cost-Benefit Analysis of Entitlement Problems: A Critique, 33 STAN. L. REV. 387, 425-30 (1981); Arthur Leff, Economic Analysis of Law: Some Realism About Nominalism, 60 VA. L. REV. 451, 478-79 (1974). Daniel Bromley argues persuasively that the advocates of privatization solutions to environmental problems tend to ignore the problems posed by wealth effects and the endowment effect, and thus fail to see how the initial distribution of entitlements defines the "optimal" outcome. See DANIEL W. BROMLEY, Environment and ECONomy: Property Rights And PUblic Policy 18, 37, 44, 49, 76 (1991).

29. See Matthew D. Adler \& Eric A. Posner, Implementing Cost-Benefit Analysis When Preferences are Distorted, 29 J. LEGAL STUD. 1105 (2000); Daniel A. Farber, The Problematics of the Pareto Principle, U.C. BERKELEY PUBLIC LAW AND LeGal Theory ReSEARCH SERIES, Research Paper No. 114, Feb. 20, 2003, http://papers.ssrn.com/sol3/papers.cfm?abstract_id=384142 (follow "New York USA" hyperlink under download section).

30. See Robert C. Ellickson, Bringing Culture and Human Frailty to Rational Actors: A Critique of Classical Law and Economics, 65 CHI.-KENT L. REV. 23, 3555 (1989); John D. Hanson \& Douglas A. Kysar, Taking Behavioralism Seriously: The Problem of Market Manipulation, 74 N.Y.U. L. REV. 630, 640-87 (1999); Peter H. Huang, Reasons Within Passions: Emotions and Intentions in Property Rights Bargaining, 79 OR. L. REV. 435 (2000); Paul Slovic, Trust, Emotion, Sex, Politics, and Science: Surveying the Risk Assessment Battlefield, in THE PERCEPTION OF RISK 390, 396-402 (Paul Slovic ed., 2000).

31. See Amy Sinden, Cass Sunstein's Cost-Benefit Lite: Economics for Liberals, 29 ColUM. J. ENVL. L. 191, 201-12 (2004); Amy Sinden, In Defense of Absolutes: Combating the Politics of Power in Environmental Law, 90 IOWA L. REV. 1405, 1423-30 (2005) [hereinafter Sinden, In Defense]; Amy Sinden, The Economics of Endangered Species: Why Less is More in the Economic Analysis of Critical Habitat Designations, 28 HARV. ENVTL. L. REV. 129, 197-208 (2004). 
in the following pages, I assume that aggregate consumer willingness to pay as expressed in markets is a legitimate measure of social welfare. My aim here is not to critique those assumptions (though that is a worthy project), but rather to show that, even assuming those assumptions to be true, the claim that private property or market regimes can solve tragedies of the commons in the real world is unconvincing.

\section{B. The Tragedy of the Commons and the Problem of Market Failure}

Under the set of theoretical assumptions made by neoclassical economics, a perfectly competitive market (or a system of perfectly competitive markets) ${ }^{32}$ will reach a point of Pareto efficiency in which the consumer good (or goods) at issue is produced in the quantity that maximizes overall social welfare. Where, however, there are externalities-where some of the costs (or benefits) of an activity are not borne by the decision maker engaging in that activity-the market will fail to produce an optimal result. ${ }^{33}$ If the externality is negative-a cost not borne by the decision maker-then the market will overproduce the product associated with it. If the externality is positive - a benefit not borne by the decision maker-then the market will under-produce the associated product.

Externalities may affect many people (as where a factory emits pollution into the air) or just a few (as where the noise and vibrations from the machinery operated by a confectioner disturbs a neighboring doctor in his work). ${ }^{34}$ Many large-scope externalities can be conceptualized as situations in which there is some resource-the air, for example - that is not owned by any individual and therefore is open to use by a large group of people. In such circumstances, any one individual's decision to use a unit of the resource or to dispose of waste in the resource is likely to impose costs on the whole group, only a fraction of which will be borne by the individual decision maker. Because of these pervasive externalities, the individually rational ac-

32. A general equilibrium analysis would reach the same conclusion of a Pareto efficient equilibrium under a system of perfectly competitive interdependent markets. See supra notes 23-24 and accompanying text.

33. TOM TIETENBERG, ENVIRONMENTAL AND NATURAL RESOURCE ECONOMICS 51-54 (1992).

34. See Ronald Coase, The Problem of Social Cost, 3 J.L. \& EcoN, 1, 2 (1960). 
tions of each user will add up to a result that is bad for everyone-the over-exploitation of the resource.

In a now famous 1968 essay, biologist Garrett Hardin dubbed this phenomenon "the tragedy of the commons." $35 \mathrm{He}$ illustrated the problem by describing a pasture open to a large group of cattle herders. Each herder, in deciding whether to add additional cattle to her herd, seeks to maximize her own gain. But the open pasture presents a classic externality problem. While each cattle herder bears the full benefit of adding an additional cow to her herd, she bears only a small fraction of the cost. The remaining costs of any overgrazing of the commons that results are externalities borne by the other cattle herders. Accordingly, because she only accounts for a fraction of the costs, each herder continues adding cattle to her herd until the total number of cattle on the commons exceeds the carrying capacity of the pasture. In this way, said Hardin, "[f]reedom in a commons brings ruin to all."36 It is a powerful parable, because, as Hardin noted, this particular iteration of the externality problem forms the root of virtually all environmental problems, from the over-exploitation of forests and fisheries to the pollution of air and water. ${ }^{37}$

\section{Solving the Tragedy}

Hardin identified two possible solutions to the tragedy. One was to sell the commons off as private property. ${ }^{38}$ The other was "mutual coercion, mutually agreed upon"-i.e., government regulation. ${ }^{39}$ Subsequently, Hardin was criticized for not recognizing that common ownership regimes can also in

35. Hardin, supra note 1, at 1244. Hardin was not the first to identify this phenomenon. See Scott Gordon, The Economic Theory of a Common Property Resource: The Fishery, 62 J. POL. ECON. 124 (1954); Anthony Scott, The Fishery: The Objectives of Sole Ownership, 63 J. POL. ECON. 116 (1955). Indeed, an understanding of this problem goes all the way back to Aristotle. See ELINOR OSTROM, GOVERNING THE COMMONS: THE Evolution OF INSTITUTIONS FOR COLLECTIVE ACTION 2 (1990).

36. Hardin, supra note 1 , at 1244.

37. See id. at 1245-46 (noting the tragedy of the commons with respect to fish and whales in the oceans, over use of the national parks, pollution, and world population); Carol M. Rose, Rethinking Environmental Controls: Management Strategies for Common Resources, 1991 DUKE L. J. 1, 3 (1991) (characterizing all environmental problems as commons problems).

38. See Hardin, supra note 1 , at 1245 .

39. Id. at 1247 . 
some circumstances avert the tragedy of the commons. Elinor Ostrom and others conducted extensive empirical research in the 1980 s and 1990s that uncovered numerous examples of situations in which a resource was commonly owned by a group of people who excluded outsiders and kept use of the resource at sustainable levels by a set of internally agreed-upon rules. ${ }^{40}$

Ostrom's insight made clear that Hardin had not been precise enough in his definition of the problem. Part of the confusion lay in his terminology. The phrase "the commons" tends to conflate two distinct regimes: common ownership regimes and open access regimes. ${ }^{41}$ The former is a property rights system-group members jointly hold property rights in the resource as against the rest of the world. Thus, while they cannot exclude each other from the resource, they can exclude outsiders. An open-access regime, on the other hand, is an absence of property rights. Hardin's tragedy of the commons really applies only to the latter situation, not the former, and, as several thinkers have pointed out, is better conceptualized as "the tragedy of open access." 42

At this point, then, we can add a third solution to the two that Hardin identified: common ownership. 43 Interestingly, this solution has probably been the least controversial of the three, perhaps because it seems to offer something for everyone. Those on the left view it as a testament to the triumph of collectivism over individualism, and free-market environmentalists like it because they view it as something other than government regulation and therefore good. ${ }^{44}$

Indeed, at least in those circumstances where they work,

40. See OSTROM, supra note 35; see also Susan Jane Buck Cox, No Tragedy on the Commons, 7 ENVTL. ETHICS 49 (1985); Robert C. Ellickson, Property in Land, 102 YALE L.J. 1315, 1388-91 (1993) (noting ability of close-knit social groups to develop internal social controls to avoid the tragedy of the commons).

41. See Ellickson, supra note 40, at 1381 ("All analysts now agree that it is important to distinguish, as Hardin did not, between open-access territories that anyone may enter and tracts that are accessible only to the members of a limited populace and their licensees."); COLE, supra note 8, at 11.

42. See COLE, supra note 8 , at 11 ; BROMLEY, supra note 28 , at 22 . Bromley argues that this confusion is in part responsible for the prevalence of the simplistic and unexamined assumption that private property rights will necessarily solve commons problems. Id. at 23.

43. Abraham Bell \& Gideon Parchomovsky, Of Property and Antiproperty, 102 MICH. L. REV. 1, 41 (2003) (calling common ownership regimes described by Ostrom "a third remedy" to the tragedy of the commons).

44. See ANDERSON \& LEAL, supra note 7, at 143-57 (praising common ownership regimes and describing the circumstances in which they succeed). 
common ownership regimes really do seem to offer a third way out of the tragedy that resists categorization as either a government regulation or a private property/market regime. While common ownership regimes do involve a form of property that could be described as private (though not individual), they differ from private property regimes in a crucial respect: they do not answer the "how much" question through markets. Instead, they answer it through a form of collective (political) decision making. Yet it is also not entirely accurate to describe them as small-scale government regulation. Ostrom has convincingly argued that the community-level decision making that occurs under common ownership regimes is marked by the active involvement of group members and thus fundamentally different in kind from traditional government regulation, which is typically formulated on a much larger scale by bureaucrats who are often geographically and culturally far removed from the resource at issue. ${ }^{45}$

Unfortunately, despite the remarkable degree of consensus they generate, common property regimes don't really get us very far in terms of solving the tragedy of the commons in most real-world situations. As Ostrom's analysis has shown, such regimes only really work under a particularized set of cultural conditions that are becoming ever less common as small communities become increasingly integrated into a global economy. ${ }^{46}$ The keys to the success of such regimes seem to be relatively small size, stable membership, and a homogenous culture where norms of reciprocity and trust predominate. ${ }^{47}$ Thus, while they provide an attractive alternative in those circumstances where they work, in many situations, common ownership will not present a realistic alternative. That leaves us, in most instances, confronting the choice that Hardin originally presented: government regulation or privatization..$^{48}$ This

45. See OSTROM, supra note 35 , at 41 ; see also COLE, supra note 8 , at 111 ("[C]ommon property systems are not managed by politicians and bureaucrats in some faraway capital but by the co-owners themselves, collectively."). But see ShiLing Hsu, A Two-Dimensional Framework for Analyzing Property Rights Regimes, 36 U.C. DAVIS L. REV. 813, 846 (2003) (suggesting that common ownership regimes may not be efficient where the resource has global in addition to local value and there is a divergence between local and global optima).

46. See Hsu, supra note 45 , at 850.

47. See OSTROM, supra note 35 , at 211 .

48. For an innovative proposal for a fourth solution to the commons problems that impede the preservation of public park land, see Bell \& Parchomovsky, supra note 43 , at 45 (advocating the formalization of "anti-property easements" in own- 
is where the consensus breaks down, and the rest of this article will accordingly focus on that choice.

\section{The Government Regulation Solutions}

Government regulation aimed at solving environmental commons problems may take a variety of forms. It is often divided into two types: command-and-control regulation and economic incentive regulation. Under a command-and-control regime, government directs private parties to take certain actions-to install a particular pollution control device, for example. This type of regulation is contrasted with "economic incentive regulation"-like pollution taxes or environmental trading markets (ETMs) ${ }^{49}$ - under which government provides an economic incentive for actors to take certain measures.

This dichotomy, however, is far too simplistic and highly misleading. ${ }^{50}$ The line between command-and-control regulation and economic incentive regulation is not nearly so clear as the dichotomy suggests. Traditional command-and-control regulation also operates by way of economic incentives. Regulated entities comply with government rules precisely because they have an economic incentive to do so in the form of fees or penalties that will be assessed for noncompliance (assuming effective enforcement). Conversely, so-called economic incentive programs also depend on government command to a substantial degree. Under a pollution tax regime, for example, government makes the crucial decision to impose a tax at a particular level, which determines how much regulated entities will reduce pollution levels and how much pollution in the aggregate will ultimately be produced. Similarly, under an ETM, government decides where to set the cap on overall resource use or pollution levels. ${ }^{51}$

Moreover, the common assertion that our current constel-

ers of property adjacent to public park lands).

49. Under an ETM, government sets a cap on overall resource use or pollution levels, distributes to those engaged in the relevant activity a number of permits equivalent to the cap, and then allows the permits to be traded. For a more indepth discussion of ETMs, see infra Part II.A.

50. See Jody Freeman \& Daniel A. Farber, Modular Environmental Regulation, 54 DUKE L.J. 795, 819-20 (2005); David M. Driesen, Is Emissions Trading an Economic Incentive Program?: Replacing the Command and Control/Economic Incentive Dichotomy, 55 WASH. \& LEE L. REV. 289 (1998).

51. For a more in-depth discussion of ETMs, see infra Part II.A. 
lation of federal environmental statutes relies primarily on command-and-control regulation is overstated. Most current regulation does not actually constitute command-and-control regulation in a strict sense.52 Rather than commanding regulated entities to take specific measures (to install a particular type of pollution control technology, for example), most environmental statutes direct agencies to simply specify a performance standard-a level of environmental performance that must be met to avoid penalties-leaving the method of compliance to the individual firm. ${ }^{33}$ The confusion arises in part because many pollution standards are said to be "technologybased." This, however, refers to the method the agency uses to set the standard (to answer the "how much" question) rather than the form that the standard ultimately takes. Thus, EPA will typically set a performance standard (a level of pollution reduction) at the level that is achievable with the technology currently available (or sometimes with a technology the agency anticipates will be available in the future). But polluters are generally free to use any technology or method they choose in order to meet that standard. ${ }^{54}$ Even where statutes do command use of a particular technology, they usually require the administering agency to approve alternative technologies that can be shown to meet the same level of performance. ${ }^{55}$ Thus,

52. See ClIFFORD S. RUSSELL, APPLYING ECONOMICS TO THE ENVIRONMENT 190-91 (2001) (noting that the term "command-and-control" is used to refer to any form of regulation that cannot be specifically categorized as "economic incentive" or "market-based instrument").

53. Driesen, supra note 50, at 297-98. See, for example, Section 111(a)(1) of the Clean Air Act, 42 U.S.C. $\S 7411$ (a)(1) (2000), which defines "standard of performance" as "a standard for emissions of air polluntants which reflects the degree of emission limitation achievable through the application of the best system of emission reduction which ... the [EPA] determines has been adequately demonstrated." See also PPG Indus., Inc. v. Harrison, 660 F.2d 628, 636 (5th Cir. 1981) (holding that standards of performance must be "established only in the form of emissinos limitations based on output, and not in the form of work practice or operation requirements").

54. Driesen, supra note 50, at 297-98. Section 304 of the Clean Water Act requires the EPA to "identify in terms of amounts ... the degree of effluent reduction attainable through the application of best practicable control technology." Clean Water Act, 33 U.S.C. $§ 1314($ b)(1)(A) (2000).

55. Driesen, supra note 50, at 298-99. Governing the promulgation of work practice standards for new sources where performance standards are not feasible, Section 111(h) of the Clean Air Act states:

If . . . any person establishes to the satisfaction of the [EPA] that an alternative means of emission limitation will achieve a reduction in emissions of any air pollutant at least equivalent to the redutction in emis- 
David Driesen concludes that "[t]rue command and control regulations are the exception rather than the rule." 56

In fact, government regulation takes a variety of forms, each of which contains elements of command and elements of economic incentive. These varieties of regulation can be conceptualized on a continuum. At one extreme, government actually owns the resource in question. The federally owned lands in the western United States are a prominent example. ${ }^{57}$ It can then exclude some users (command) and charge fees to others for use (a combination of command and incentive). Alternatively, resources may be privately owned, but government may issue command-and-control regulations imposing specific conditions on use, for example by requiring polluting facilities to install particular pollution control devices (command), and imposing a fee for noncompliance (incentive).

Other forms of regulation involve progressively less of a role for government command and more of a role for economic incentives. For example, government may require facilities to comply with certain performance standards (command), but allow them discretion in what methods they use to comply, thus creating an economic incentive to develop cheaper technologies. Or, government may require polluting facilities to pay a tax on the pollution they produce (command), thus creating an incentive to reduce pollution levels in order to lessen tax liability. 58 Alternatively, government may create an ETM, imposing a cap on overall emissions and issuing individual tradable permits in that amount (command), thus creating an incentive for firms to find cheap methods to reduce pollution levels in order to sell excess permits.

Another method that is becoming increasingly popular is informational regulation. This may take the form of government itself providing information and education to the public on the adverse environmental effects of various activities, thus creating a (weak) incentive for private actors to voluntarily al-

sions of such air pollutant achieved under the requirements of paragraph (1), the [EPA] shall permit the use of such alternative . . for purposes of compliance with this section....

42 U.S.C. $\$ 7411(h)(3)$.

56. Driesen, supra note 50, at 299.

57. See COLE, supra note 8 , at 7 (characterizing government regulation as a form of public property).

58. Conversely, government may create a similar effect by paying subsidies to facilities that reduce pollution by particular amounts. 
ter their own conduct. 59 Alternatively, government may require private firms to provide the public with information and data on the environmental harms they cause (command), thus creating incentives for firms to reduce harms in response to consumer pressures. ${ }^{60}$

Indeed, as many commentators have pointed out, even a private property regime requires a role for government in the definition and enforcement of property rights, and thus can be characterized as a form of government regulation. ${ }^{61}$ Thus, we might arrange the various forms of government regulation along the following continuum from more to less government control:

59. See James Salzman, Creating Markets for Ecosystem Services: Notes from the Field, 80 N.Y.U. L. REv. 870, 885 (2005) (giving the example of recreational boaters, who began developing an ethic of not dropping anchors on coral reefs after becoming informed of the harm caused by their acts).

60. See generally David W. Case, Corporate Environmental Reporting as Informational Regulation: A Law and Economics Perspective, 76 U. COLO. L. REV. 379 (2005).

61. See Robert C. Ellickson, Three Systems of Land-Use Control, 13 HARV. J.L. \& PUB. POL'Y 67, 68 (1990) ("What we ordinarily think of as private property . . . is a form of regulation. . . [Even] Blackstonian property rests on, indeed consists of, a set of government regulations that prohibits outsiders from trespassing, encroaching, or otherwise interfering with a landowner's possession and use of land."); FREYFogle, THE LAND We SHARE, supra note 27, at 15 ("Property . . . is an individual right that is curiously dependent upon laws enacted by the majority for public aims."); id. at 173; JOSEPH WILlaM SingER, ENTITLEMENT: THE PARADOXES OF PROPERTY 7 (2000); James Krier, The Tragedy of the Commons Part II, 15 HARV. J.L. \& PUB. POL'Y 325, 328-29 (1992); Posner, supra note 23, at 383 ("The choice is rarely between a free market and public regulation. It is between two methods of public control-the common law system of privately enforced rights and the administrative system of direct public control . ..."). But see Jonathan H. Adler, Legal Obstacles to Private Ordering in Marine Fisheries, 8 ROGER WILLIAMS U. L. REV. 9, 23 (2002) (arguing that "de facto property rights may emerge absent government action").

Conversely, one can also characterize government regulation as simply another property regime, as Daniel Cole has done. See COLE, supra note 8, at 7 (conceptualizing government regulation of environmental problems as an assertion of public property rights in the resource at issue); Hsu, supra note 45 , at 855 (characterizing government regulation as a type of property rights regime); J. Peter Byrne, Property and Environment: Thoughts on an Evolving Relationship, 28 HARV. J.L. \& PUB. POL'Y 679, 683 (2004) ("[E]nvironmental regulations appear to be a part of the property system, rather than external to it."). 
Table 1: Forms of Governmental Regulation

\begin{tabular}{|c|c|c|c|}
\hline & $\begin{array}{l}\text { Type of Govern- } \\
\text { ment Regulation }\end{array}$ & $\begin{array}{c}\text { Traditional } \\
\text { Categorization }\end{array}$ & $\begin{array}{l}\text { My Categori- } \\
\text { zation }\end{array}$ \\
\hline \multirow{7}{*}{$\begin{array}{l}\text { More } \\
\text { Government } \\
\text { Control }\end{array}$} & $\begin{array}{l}\text { Government (public) } \\
\text { ownership }\end{array}$ & \multirow{3}{*}{$\begin{array}{l}\text { Command \& } \\
\text { control }\end{array}$} & \multirow{5}{*}{$\begin{array}{l}\text { Government } \\
\text { Answers the } \\
\text { "How Much" } \\
\text { Question }\end{array}$} \\
\hline & $\begin{array}{l}\text { Command-and- } \\
\text { control (specific } \\
\text { methods and } \\
\text { technologies) }\end{array}$ & & \\
\hline & $\begin{array}{l}\text { Performance } \\
\text { standards }\end{array}$ & & \\
\hline & $\begin{array}{l}\text { Environmental } \\
\text { Trading Markets }\end{array}$ & \multirow{5}{*}{$\begin{array}{l}\text { Economic } \\
\text { incentive }\end{array}$} & \\
\hline & Taxes/Subsidies & & \\
\hline & $\begin{array}{l}\text { Mandated disclosure } \\
\text { of information by } \\
\text { private parties }\end{array}$ & & \multirow{3}{*}{$\begin{array}{c}\text { Market } \\
\text { Answers the } \\
\text { "How Much" } \\
\text { Question }\end{array}$} \\
\hline & $\begin{array}{l}\text { Provision of } \\
\text { information by the } \\
\text { government } \\
\text { (persuasion) }\end{array}$ & & \\
\hline $\begin{array}{l}\text { Less } \\
\text { Government } \\
\text { Control }\end{array}$ & $\begin{array}{l}\text { Definition and } \\
\text { enforcement of } \\
\text { private property } \\
\text { rights }\end{array}$ & & \\
\hline
\end{tabular}

As described above, there is a tendency in the literature to draw a line between performance standards and ETMs, and to call everything above the line a form of command-and-control regulation and everything below the line an economic incentive or privatization model. While there certainly are important distinctions between command-and-control and performance standards regulation on the one hand and taxes, subsidies and ETMs on the other, as I argue above, these distinctions have been vastly overdrawn. All of those methods of regulation involve some elements of command and some elements of economic incentive.

A far more useful and meaningful categorization distin- 
guishes the various approaches based on who answers the "how much" question. If we draw a line between taxes/subsidies and informational regulation, then for all those methods above the line, government answers the "how much" question, while for all those below the line, the market answers the "how much" question. I will elaborate this point in more detail in Part II.A., but for now, suffice it to say that under an ETM, government answers the "how much" question by setting the cap on overall resource use or pollution, and under a regime of pollution taxes it performs essentially the same function by setting the amount of the tax (which ultimately determines the overall level of pollution). ${ }^{62}$ Under information regulation, on the other hand, government simply reduces informational transaction costs, but the "how much" question remains with the market. ${ }^{63}$ This distinction based on who answers the "how much" question provides a far more useful and analytically relevant line because it distinguishes those methods that rely on the free market to determine the optimal level of environmental degradation from those methods that require government to selfconsciously choose the optimal level. ${ }^{64}$

62. It is ironic that emissions trading has come to be something of a poster child for the privatization alternative to government regulation of environmental harms, because when the idea was first unveiled in the legal literature in the $1980 \mathrm{~s}$, it was sold as a sort of new and improved version of emissions taxes, which are usually viewed by economists as the prototypical example of government regulation. Richard Stewart, for example, in his early writings on the subject, characterized emissions trading and emissions taxes as members of the same family of "economic incentive systems." Stewart, supra note 5, at 158.

63. Under a regime of informational regulation, the government does not determine a desired or optimal level of environmental degradation. Rather, it simply produces information (or requires it to be produced) and then relies on the free market to set the resulting level of degradation. Where, for example, the Toxic Release Inventory makes information about the levels of toxic pollution produced by a company available to consumers, market pressures in the form of reduced consumer willingness to pay for a pollution producing product may cause the company to reduce pollution levels. See Case, supra note 60, at 414-26. Informational regulation can be conceptualized as a method of reducing transaction costs in order to make the market more closely approximate a perfectly competitive market.

64. Where government chooses the optimal level, it may use cost-benefit analysis to try to mimic the efficient outcome that a market would have produced, or it may apply some entirely different normative scheme that, for example, sets the optimal level based on the requirements of human or ecological health without regard to costs, or based on a moral imperative that industries must reduce pollution as much as possible. See DaNIEL A. FARBER, Eco-Pragmatism: MAKING SENSIBLE ENVIRONMENTAL DECISIONS IN AN UNCERTAIN WORLD 41, 72, 107-09 (1999); Wendy E. Wagner, The Triumph of Technology-Based Standards, 2000 
In theory, one might conceptualize pollution taxes as leaving the "how much" question to the market and therefore categorize them "below the line." In an ideal world, government might quantify and monetize the precise amount of harm caused to society by each unit of pollution, and then assess a tax on polluters in that amount. Once the externality had thus been internalized by the tax, the market would produce the efficient (or welfare maximizing) level of overall pollution. I have nonetheless chosen to categorize taxes "above the line" because I suspect that in practice, tax rates are highly unlikely to be set in that manner. The informational barriers to quantifying the social welfare cost imposed by each unit of pollution are insurmountable. Accordingly, it is far more likely that government would proceed instead by setting a target for overall pollution levels (much as it does in setting the cap for an ETM) and then working backward to set the tax at a level likely to produce roughly that level of total pollution. 65

Thus, even though privatization can be characterized as a form of government regulation, ${ }^{66}$ for the present purposes, I am defining government regulation more narrowly to mean those methods for addressing environmental commons problems under which the government-rather than the market-answers the "how much" question.

\section{The Privatization Solutions}

The alternative to government regulation is to divide the commons into private property and let the free market answer the "how much" question. This is usually treated as a single solution to the tragedy of the commons-"the privatization solution." 67 But actually it conflates two very distinct mechanisms by which the tragedy can be solved. One, which I will call "the private property solution," divides the commons into

ILL. L. REV. 83, 92.

65. See Stewart, supra note 5, at 159 ("Under a pollution fee or tax system the level of the charge is set to induce control responses by firms that, in the aggregate, will reduce pollution sufficiently to achieve the environmental goal.").

66. See FREYFogle, The LAND We SHARE, supra note 27, at 173 ("Hardin's . . . two solutions were ... variants on a single solution. ... [P] rivate property itself ... is a form of mutual coercion, mutually agreed upon.").

67. For a far more modest claim that widespread ownership of private property creates a political culture that favors environmental protection by creating a "private property lobby," see Thomas W. Merrill, Private Property and the Politics of Environmental Protection, 28 HARV. J.L. \& PUB. POL'Y 69, 71 (2004). 
private parcels in such a way that all externalities are eliminated (that is, all costs and benefits of a property owner's activities accrue to that owner). The other, which I will call "the market solution," eliminates or minimizes transaction costs such that all those affected by the externalities can engage in Coasian bargaining in order to achieve economically efficient (welfare maximizing) pollution or resource extraction levels. ${ }^{68}$

\section{a. The Private Property Solution}

Although he was not very specific, what Hardin himself was probably talking about when he made reference to averting the tragedy through privatization was what I am calling "the private property solution"-the idea of literally dividing the commons into separate parcels of land owned by individual cattle herders, each of whom confines her cattle to her own plot. 69 Hardin no doubt assumed that under such a regime, each cattle herder would bear both the full benefits and the full costs of her decisions. When she added an additional cow to her herd, she would reap the full benefit of being able to sell the added cow at the market but would also bear the full burden of the additional grazing pressure imposed on her piece of land by a larger herd. Accordingly, since the full costs and benefits to society as a whole of her decisions would be congruent with the costs and benefits borne individually by her, the cattle herder's private cost-benefit analysis would yield a result that was optimal for society as well as for her. All externalities would be internalized and the tragedy of the commons would be solved.

Note, however, that not all divisions of the commons into private property will accomplish this result. Imagine, for example, that one particular species of grass provides the most efficient food for cows, so that planting one's entire plot with that grass allows one to support the biggest herd. But further imagine that if the entire commons is planted in this one species, the result will be an ecologically fragile monoculture, far

68. See Coase, supra note 34, at 2-15. Harold Demsetz recognized these two different solutions to the tragedy of the commons in his response to Coase. See Harold Demsetz, Ownership and the Externality Problem, in PROPERTY RIGHTS: CoOperation, CONFlict, and LaW 282, 290 (Terry L. Anderson \& Fred S. McChesney eds., 2003).

69. See Hardin, supra note 1, at 1244; see also Harold Demsetz, Toward a Theory of Property Rights, in OWNERSHIP, CONTROL AND THE FIRM: THE ORGANIZATION OF ECONOMIC ACTIVITY, Vol. I, 111 (1988). 
more susceptible to diseases than the ecosystem would be if one-tenth of the entire pasture were planted in a mix of native grasses (less tasty to cattle). Reserving any less than one-tenth of the entire pasture for native grasses will have no beneficial effect. Under these circumstances, simply dividing the commons into private property will not solve the tragedy. If each herder acts rationally to maximize her own advantage, she will plant her entire plot in monoculture, thus increasing the probability that the whole pasture will be destroyed by disease. All would be better off if each herder planted one-tenth of her plot in native plants, but without assurance that others will do the same, no one herder will have an incentive to sacrifice her overall yield.

Similarly, imagine that each cattle herder can grow more grass and therefore support more cattle on a given plot of ground by using large amounts of inorganic fertilizer but that if she does so, the fertilizer residue will run off into a nearby trout stream, drastically altering the aquatic ecosystem, killing fish, and negatively affecting all those who benefit from a healthy stream, including downstream fishermen. Again, the commons has been privatized, but tragedy persists.

Thus, dividing an open access resource into private property does not in itself solve all commons problems that may be associated with the use of that resource. ${ }^{70}$ There is a crucial condition that must be met in order for an allocation of the commons into private property to effectuate a solution to the tragedy: there must be no remaining externalities or spillover effects-each private property owner must bear the full social costs and benefits of her actions. ${ }^{71}$ In some cases this will be

70. Many authors seem to miss this point. See, e.g., Adler, supra note 61, at 13 ("The creation of property rights is the most obvious means of preventing the tragedy of the commons. As a general rule, where resources are owned, there is less concern about their overuse.") (citation omitted); ANDERSON \& LEAL, supra note 7 , at 22 (establishing private property rights as the "key" to solving commons problems). But see David Schmidtz, The Institution of Property, in THE COMMON LAW AND THE ENVIRONMENT: RETHINKING THE STATUTORY BASIS FOR MODERN ENVIRONMENTAL LAW 109, 121 (Roger E. Meiners \& Andrew P. Morriss eds., 2000) ("Clearly, not all forms of privatization are equally good at internalizing externalities."); Bell \& Parchomovsky, supra note 43 , at 43 ("It is important to note that private property does not eliminate all externalities.").

71. See Adler, supra note 61 , at 20 ("What is most important is that the property be allocated on a 'scale' sufficient to eliminate-or at least mitigate-a commons problem."). Another example of this principle comes from oil and natural gas law. Typically, many firms own surface property rights that allow them to drill into and extract oil or gas from a common pool. Because firms do not gain 
easier than in others. The grass eating commons problem is relatively easy to solve. Dividing the commons into private plots of virtually any size will internalize the externality by causing each herder to bear the full cost of the grass her cows consume. ${ }^{72}$ But the monoculture commons problem is far more difficult. Any property boundaries that encompass something less than the entire original commons (i.e., the entire ecosystem) will still be leaky such that externalities remain. And in the commons problem posed by the fertilizer polluting the stream, internalizing all the externalities would require vesting ownership of the entire pasture and the stream in a single owner. ${ }^{73}$

In general, in order for the private property solution to work, private property boundaries must be drawn to match the scope of the relevant externality. To solve the fertilizer tragedy, for example, a single parcel of private property would have to encompass the full area of the entire ecosystem affected by the resulting water pollution. The only exception to this rule is "pure consumption" commons problems, like the grass-eating externality. Where the commons problem stems solely from the fact that one user's consumption of a unit of the resource diminishes the amount available to others, then the tragedy may be solved by dividing the resource into parcels of private property that are smaller than the scope of the original externality. Thus, even though the scope of the original externality

property rights over the oil or gas itself until they extract it, a tragedy of the commons ensues despite the existence of private property rights in the subsurface resources. One solution is to consolidate ownership over the entire pool in a single firm, thus internalizing the externalities-a process called "unitization." See Gary Libecap, Unitization, in NEW PALGRAVE DICTIONARY OF ECONOMICS AND THE LAW (forthcoming).

72. This assumes the landowner has perfect information about sustainable consumption levels. See infra notes 176-81 and accompanying text.

73. Free market environmentalists often assert or imply that the market will naturally consolidate or divide parcels into the optimal size. See, e.g., Terry L. Anderson, Vernon L. Smith, and Emily Simmons, How and Why to Privatize Federal Lands, POLICY ANALYSIS No. 363 at 14 (1999); Demsetz, supra note 68, at 286 . But this of course wrongly assumes that the market somehow already takes externalities into account-that, for example, transaction costs are zero or de minimis. If, on the other hand, we assume a more realistic scenario in which transaction costs are substantial and would accordingly prevent all those harmed by a factory's pollution from either suing for an injunction or getting together to offer the factory owner a bribe (depending on the legal rule), then the factory owner would have no incentive to acquire the land affected by the factory's externalities. Indeed, she would have a clear incentive not to, since such lands would incur costs that she would not otherwise have to bear. 
that formed the basis of the tragedy on Hardin's cow pasture encompassed the entire commons, the problem could be solved by dividing the commons into many smaller parcels of private property. This is because, in a pure consumption commons problem, the scope of the externality is solely a product of the legal arrangement. The only reason that cattle herder $B$ is harmed by cattle herder A's consumption of additional grass is because the legal arrangement (the open access commons) gives cattle herder $\mathrm{B}$ an expectation that she may be able to lay claim to those same blades of grass. Accordingly, once the legal arrangement is changed by the delineation of property boundaries, the scope of the impact caused by grass consumption shrinks to the size of each private parcel, and the externalities are internalized.

In all other commons problems, the scope of the externality is physically, not legally, determined. Thus, where the commons problem stems from air pollution, water pollution, or other ecosystem impacts, the externality affects some physical space, the dimensions and contours of which cannot be altered by the drawing of property boundaries. ${ }^{74}$ The fertilizer pollution commons problem, for example, will not be solved by dividing the watershed into smaller parcels of private property. Pollution will flow across property boundaries, fish made sick by the pollution will swim (or fail to swim) across property boundaries, and wildlife dependent on fish for food will walk (or fail to walk) across property boundaries. ${ }^{75}$ Externalities will remain, and the tragedy of the commons will persist.

Even though the pure consumption commons problem is the primary example that Hardin used, and even though it continues to dominate our way of thinking about the problem, examples of pure consumption commons problems unaccompanied by closely linked physical commons problems are difficult to find in the real world. Consider, for example, the other frequently-cited example of the tragedy-the open access fishery. This is a consumption commons problem to the extent that it arises because each time a fisherman catches a fish, every other fisherman's chances of catching another fish are diminished. But consider what happens if we try to solve the prob-

74. See Eric T. Freyfogle, Bounded People, Boundless lands: EnVISIONING A NEW LAND ETHIC 3-16 (1998) [herinafter Freyfolge, BOUNDEd PEOPLE].

75. See FREYFogLe, THE LAND WE SHARE, supra note 27 , at 167. 
lem by dividing the resource into parcels of private property of any random size, as we did on Garrett Hardin's pasture. If the technology were available to tag and track each fish, ${ }^{76}$ we could, for example, assign to each fisherman some number of particular fish. This would solve the consumption commons problem, because when fisherman A caught one of her radiotagged fish, fisherman B, who had no expectation or property interest in that fish to begin with, would not be able to complain. But what if the group of fish assigned to each fisherman were too small to contain sufficient genetic diversity to maintain a healthy, reproductively self-sustaining population? What if each fisherman had to depend on her fish breeding with other fishermen's fish in order to produce a healthy new generation for the next season? Leaving fish in the water to breed next year would impose opportunity costs (in the form of forgone profits this year and the risk that the fish would die before next season) and, unless enough other fishermen did the same, would provide no benefit. This positive externality presents a classic prisoner's dilemma leading to a tragedy of the commons.

Thus, in addition to the pure consumption commons problem, the open access fishery involves a second, closely related commons problem. This sustainability problem is a physicalnot a consumption-commons problem. That means that in order to internalize the externality that forms the basis of the sustainability problem, property boundaries must be drawn so as to encompass the full physical scope of the externality. That is, each fisherman must be assigned property rights to a population of fish that is large enough and sufficiently genetically diverse to be reproductively self-sustaining.

The fishery involves other physical commons problems as well. Even if each private property owner manages her reproductively self-sustaining population of fish to provide a sustainable yield of that species each year, what if those management regimes reduce the overall population to a level that is no longer sufficient to support some other marine species that depends on the original fish species for food? Or what if the most productive methods for catching the original fish species produce significant by-catch of other species?77

76. See ANDERSON \& LEAL, supra note 7, at 121 (describing existing technology for tagging and tracking individual whales).

77. See Rieser, supra note 8, at 418 . 
The problem is that free market environmentalists and others often treat all commons problems as though they were pure consumption problems. Thus, the assertion is frequently made that commons problems can be solved by simply defining and enforcing private property rights of any size or contour. ${ }^{78}$ But even if pure consumption commons problems can be solved in that way, ${ }^{79}$ as the foregoing example illustrates, they rarely, if ever, occur in the real world in a pure form, entirely disentangled from innumerable physical commons problems. And physical commons problems are far less amenable to the private property solution. First, the externalities that form the basis of physical commons problems are often wide ranging, thus necessitating individual ownership of vast parcels of property. Second, the scope of impact associated with these externalities is often ill-defined, thus making the necessary parcel size uncertain. Finally, these externalities often overlap significantly, making the delineation of private property boundaries to encompass each one virtually impossible. 80 Thus, the cattle herder who considers applying polluting fertilizer to her property must also own all the downstream watercourses that would be affected by her pollution. But what of the paper factory downstream that also considers releasing pollutants into the same stream? Must the paper plant also own the stream, or must the cattle herder buy the paper plant as well? And what of the forests in the next state that are destroyed by the acid rain caused by air pollution that is produced in part by the paper plant but by other industrial facilities in other locations as well? Clearly, any attempt to encompass all physical externalities within private property boundaries can quickly spiral out of control.

In sum, while the private property solution may work for pure consumption commons problems unaccompanied by physical commons problems, such problems are difficult to find outside the hypothetical world of Garrett Hardin's cattle herders. The difficulties that consequently plague any attempt to apply the private property solution to real-world situations will be further explored in Part III.

78. See infra notes $182-84$ and accompanying text.

79. Imperfect information and excessive discounting of future harms and benefits may complicate such a solution. See infra notes 176-81 and accompanying text.

80. See FREYFOGLE, THE LAND We SHARE, supra note 27, at 168-71. 


\section{b. The Market Solution}

The "market solution" is the other distinct mechanism by which the tragedy of the commons can be solved without recourse to government intervention. Under this solution, property rights may be defined such that externalities remain, but transaction costs must be reduced, eliminated, or minimized so that the parties affected by the externalities will bargain to reach the optimal level of pollution or resource exploitation. This solution is based on the famous theory of Ronald Coase set forth in his 1960 essay, The Problem of Social Cost. ${ }^{81}$ Coase argued that in a perfect market with no transaction costs, the parties to an externality would engage in bargaining, the outcome of which would reduce the interference with each party's property rights to the economically efficient level. He further argued that the same economically efficient resolution of the conflict would result from this bargaining regardless of which party was assigned the initial entitlement by law (for example, whether the polluter had a right to pollute or those harmed by the pollution had a right to enjoin it). 82

We can illustrate the Coase theorem using the example described above-the cattle herders using fertilizers that pollute a nearby stream. ${ }^{83}$ First, we must imagine a world with no transaction costs. This means that the cattle herders and the fishermen all have perfect information about the dollar amount of the harm caused by the pollution and the dollar cost to the herders of curtailing their fertilizer use, that all of those harmed and benefited by the fertilizer use can be identified and located without cost, that bargaining is costless, and that the

81. See Coase, supra note 34 , at $2-15$.

82. Coase himself, of course, recognized that transaction costs would prevent this result from occurring in the real world. See id. at 15. Indeed, the main point of his article was not to consider what would happen in the hypothetical world of no transaction costs, but, rather, to urge people to consider how the existence of transaction costs in the real world affects the choice of which social institutionsmarkets, government, or private firms-are likely to achieve the most efficient results in particular situations. See generally Daniel A. Farber, Parody Lost/Pragmatism Regained: The Ironic History of the Coase Theorem, 83 VA. L. REV. 397 (1997). Indeed, it may be somewhat misleading to associate the market solution to the tragedy of the commons with Coase, since Coase would probably be the first to point out that a pure market solution-in which bargaining in the absence of transaction costs yields a perfectly efficient outcome-is impossible in the real world.

83. See supra notes $69-70$ and accompanying text. 
bargaining process is not marred by collective action problems or strategic behavior. ${ }^{84}$

In such a world, if the law gave the right to pollute to the herders, the fishermen would offer the herders a "bribe" to cur. tail their use of fertilizers down to the point at which the marginal cost to the herders of curtailing their fertilizer use outweighed the marginal benefit to the fishermen. On the other hand, if the law gave the fishermen a right to enjoin the herders from causing any pollution, the herders would offer a "bribe" to the fishermen to waive enforcement of the injunction so as to allow fertilizer use up to the point at which the marginal benefit to the herders of using more fertilizer no longer outweighed the marginal cost to the fishers of increased pollution. The Coase theorem demonstrates that in a perfect world, the level of fertilizer use agreed to by the parties will be the same regardless of which legal rule forms the backdrop to the negotiations and, furthermore, that this level of fertilizer use will be the economically efficient level (i.e., the level at which net benefits to society are maximized). ${ }^{85}$ Thus, where the condition of zero transactions costs is met, pollution will be produced at efficient levels and the tragedy of the commons will be averted. 86

84. See generally Mancur Olson, The Logic of Collective Action: Public GOODS AND THE THEORY OF GROUPS (1965).

85. In some instances, the transaction costs involved in one party simply buy. ing property from the other will be fewer than those involved in negotiating over externalities. Such a purchase will have the effect of internalizing the externality within a single property owner, i.e., the private property solution. See Demsetz, Ownership and the Externality Problem, supra note 68, at 286-89. See also Peter N. Davis, Theories of Water Pollution Litigation, 1971 WIS. L. REV. 738, 777-79 (reporting that paper mills in Wisconsin routinely used to buy land along the riv. ers affected by their discharges).

86. While it is to some extent an esoteric point, it is worth noting that the market solution does not actually require the existence of private property rights, at least in theory. See CoLE, supra note 8, at 12-13; Dan Usher, The Coase Theorem Is Tautological, Incoherent or Wrong, 61 ECON. LETTERS 3, 4 (1998). Indeed, if we posit a world with no transaction costs, the institution of property becomes entirely unnecessary (at least from the normative standpoint of efficiency) as long as the legal system enforces people's bargains. If in that hypothetical world, individual control over plots of land was really the most efficient arrangement, then people would simply bargain with each other to reach a private-property-like arrangement through a series of individual agreements. The person with the ability to use a given plot of land most productively would be able to reach an agreement with every other person on earth by which she paid all others to agree to stay off that piece of land. See Demsetz, supra note 69, at 104 ("An owner of property rights possesses the consent of fellow men to allow him to act in particular ways."). In the real world, of course, transaction costs obviously make such an ar- 
Note that both the private property and the market solutions to the tragedy of the commons involve creating a situation in which the decision maker is forced to take into account the full social costs and benefits of her decisions. Under the private property solution, all social costs and benefits are internalized within private property boundaries and thus fall directly on the decision maker. Under the market solution, costs (and/or benefits) that initially fall on others are ultimately brought to bear on the decision maker through the negotiation process. The costs imposed on the fishermen by the cattle herders' activities, for example, are brought to bear on the herders' decision making process in the form of the money payment offered by the fishermen in exchange for reductions in fertilizer use. ${ }^{87}$ Accordingly, under the private property approach, it is crucial that all resources affected by a property owner's actions (the full scope of the externality) be consolidated in that one property owner. Similarly, under the market solution it is crucial that all those affected by the externality be involved in the Coasian negotiation. As Part III will explore, in the real world, the vast expanses of resources and/or large number of people affected by an externality (like air pollution

rangement completely impracticable. But, this thought experiment nonetheless confirms the intuition that we can think of property rights as simply a form of government regulation. See supra note 61 and accompanying text. Specifically, we can envision them as a mechanism for reducing the transaction costs that would otherwise prohibit the efficient allocation of control over resources that would result from a perfect market.

Many free-market environmentalists, in particular, tend to miss this point and wrongly identify well-defined and enforced property rights as a second precondition to the Coase theorem (along with the assumption of zero transaction costs). See Demsetz, supra note 69, at 106; Bruce Yandle, Coase, Pigou, and Environmental Rights, in WHO OWNS THE ENVIRONMENT? 119, 132 (Peter J. Hill \& Roger E. Meiners eds., 1998). On some level, the mistake is of minor importance, since, while property rights are not theoretically necessary, in the real world, the institution of property rights serves the important function of reducing transaction costs, which is the key to making the market solution work in practice. Nonetheless, the mistake betrays the extent to which the free market environmentalists' arguments are ultimately grounded not just in a normative commitment to economic efficiency (which drives the Coase theorem) but also in a libertarian attachment to private property as a pre-legal, natural right, fundamental to the protection of individual liberty against an overreaching state. See BROMLEY, supra note 28, at 4-6; Ellickson, supra note 40, at 1352.

87. Alternatively, under the other legal rule, one might say that the harm caused to the cattle herders by the fishermen's injunction against fertilizer use would be brought to bear on the fishermen's decision-making process (regarding whether to enforce the injunction) in the form of the money payment offered to them by the cattle herders. 
or ecosystem disturbances, for example) can often make these solutions unworkable. ${ }^{88}$

\section{Summary}

To recap: Under a government regulation solution to the tragedy of the commons, the government answers the "how much" question. Under a privatization solution, the market answers the "how much" question. If a privatization solution is going to solve the tragedy of the commons, it must take one of the following two forms. It must either: 1 ) divide the commons into private property in such a way as to remove all externalities (other than de minimis ones); or 2) create a regime in which transaction costs are zero (or de minimis) such that Coasian bargaining among the parties can lead to optimal pollution or resource extraction levels. In other words, in order to produce an economically efficient (welfare maximizing) result, a privatization regime must either: 1) eliminate or minimize externalities; or 2) eliminate or minimize transaction costs. ${ }^{89}$ The division of a commons into parcels of private property will not in and of itself solve the tragedy of the commons unless one of these criteria is also met.

The problem is that those who advocate various privatization schemes rarely, if ever, specify which of these idealized mechanisms their scheme is intended to replicate. ${ }^{90}$ In fact, as the remainder of this article will show, none of the private property/market regimes commonly touted as providing a privatization solution to the tragedy actually meets either condition. In some instances, the mistake is conceptual. Regimes that in fact rely on the government to answer the "how much" question are mischaracterized as privatization solutions. Part II discusses two contexts in which this conceptual mistake most commonly occurs: environmental trading markets and

88. See Jonathan R. Macey \& Henry N. Butler, Federalism and the Environment, in THE COMMON LAW AND THE ENVIRONMENT: RETHINKING THE STATUTORY BASIS FOR MODERN ENVIRONMENTAL LAW, supra note 70, at 158, 163 ("Externalities that affect a small number of economic actors [so that transaction costs are low] can be internalized by Coasian bargaining."). These problems are exacerbated by the fact that the actors rarely have perfect information about the full impacts of their activities. See infra notes 176-81 and accompanying text.

89. Cf. Bell \& Parchomovsky, supra note 43 , at 34-36, 47-48 (arguing that in some circumstances, deliberately increasing transaction costs can also serve conservation goals).

90. See infra notes $182-84$ and accompanying text. 
water markets. In other instances, the mistake occurs in the application of the concept to the circumstances likely to exist in the real world. Thus, some proposed privatization regimes do meet the conditions for a solution to the tragedy in an idealized hypothetical world, but the dynamics of ecological degradation are such that it is impossible for those idealized conditions to be met, or even reasonably approximated, in the real world. Part III details how this application mistake has been made in the context of land, oceans, and wildlife.

\section{The Conceptual Mistake}

This part examines environmental trading markets and water markets. These types of regimes are frequently talked about as though they constitute either examples of the privatization solution to the tragedy of the commons or an intermediate step in that direction. In fact, such characterizations are misleading since these regimes continue to rely on government to answer the "how much" question.

\section{A. Environmental Trading Markets}

In recent years, environmental trading markets (ETMs) have been hailed by many as the bright new hope for environmental policy. ${ }^{91}$ Perhaps because they involve property rights (of sorts) in tradable permits and because they create markets, they are frequently referenced in discussions applauding the triumph of markets over government regulation in post-coldwar society. Indeed, both the mainstream literature and the writings of the free market environmentalists are replete with references to ETMs as examples of the privatization solution to the tragedy of the commons, ${ }^{92}$ or at least a step in that direc-

91. See James Salzman \& J.B. Ruhl, Currencies and the Commodification of Environmental Law, 53 STAN. L. REV. 607, 609 (2000) ("[E]very major environmental policy review in the last five years has called for even greater use of ETMs.").

92. See, e.g., Engel \& Saleska, supra note 8, at 191 (citing proposed carbon dioxide emissions trading schemes as examples of the privatization solution to the tragedy of the commons); R. Quentin Grafton, Dale Squires \& Kevin J. Fox, Private Property and Economic Efficiency: A Study of a Common-Pool Resource, $43 \mathrm{~J}$. L. \& ECON. 679, 680, 683, 708 (2000) (treating Individual Transferable Quotas (ITQs) and emissions trading as "property rights approach[es] to the "tragedy of the commons"); Rieser, supra note 8, at 397 (discussing ETMs in the commercial fishing context-ITQs-and calling them "a 'poster child' for free market envi- 
tion. ${ }^{93}$ But the reality is that ETMs are not examples of the privatization solution, nor do they represent some intermediate step toward it. As the following discussion will demonstrate, ETMs are simply a form of government regulation and should be squarely categorized as such.

The ETM idea was first developed by Canadian economist J.H. Dales in $1968 .{ }^{94}$ But while there were a few small experiments with ETMs in the $1970 \mathrm{~s},{ }^{95}$ the idea did not really gain a foothold in environmental policy debates until the mid-1980s, when Professors Bruce Ackerman and Richard Stewart published a series of law review articles advocating the use of ETMs for the control of air pollution and other environmental problems. ${ }^{96}$ ETMs have now been implemented in a variety of settings, from air pollution to wetlands conservation to commercial fishing.

Although the details vary considerably, all these mechanisms share the same basic structure. They begin with a governmentally enforced prohibition on a particular activity (emitting pollution or harvesting a resource) in the absence of a

ronmentalism"); Rose, supra note 37, at 9-10 (characterizing ETMs as a private property solution to the tragedy of the commons); Zach Willey, Behind Schedule and Over Budget: The Case of Water, Markets, and Environment, 15 HARV. J.L. \& PUB. POL'Y 391, 392-94 (1992); Katrina Miriam Wyman, From Fur to Fish: Reconsidering the Evolution of Private Property, 80 N.Y.U. L. REV. 117, 163 (2005) (ITQs "share the same purpose as other more familiar forms of private property," e.g., improving economic efficiency).

93. See ANDERSON \& LEAL, supra note 7, at 167 ("[E]stablishing tradeable pollution permits . . . can be a step in the direction of property rights and markets."); see also id. at 183; ELIZABETH BRUBAKER, PROPERTY RIGHTS IN THE DEFENCE OF NATURE 212 (1995) ("Ideally . . . ITQ regimes for harvesting fish are just one stage in the evolution of private ownership of the fisheries."); Stewart, supra note 9, at 93 (calling the entities traded in ETMs "intermediate or hybrid" property); Bruce Yandle \& Andrew P. Morriss, The Technologies of Property Rights: Choice Among Alternative Solutions to Tragedies of the Commons, 28 ECOLOGY L. Q. 123, 129, 160-62 (2001) (calling ETMs "regulatory property" and arguing that they "offer a path for privatization" and "contain the seeds of private property solutions").

94. See J. H. Dales, Pollution, Property \& Prices: AN Essay in PolicyMAKING AND ECONOMICS 93-98 (1968).

95. EPA introduced a trading program for leaded gasoline in 1973. See 40 C.F.R. $\S 80.20$ (d) (1973), repealed by Prohibition on Gasoline Containing Lead or Lead Additives for Highway Use, 61 Fed. Reg. 3832, 3834 (Feb. 2, 1996).

96. See generally Bruce A. Ackerman \& Richard B. Stewart, Reforming Environmental Law, 37 STAN. L. REV. 1333 (1985); Bruce A. Ackerman \& Richard B. Stewart, Reforming Environmental Law: The Democratic Case for Market Incentives, 13 COLUM. J. ENVTL. L. 171 (1988); Stewart, supra note 5; Richard B. Stewart, Economics, Environment, and the Limits of Legal Control, 9 HARV. ENVTL. L. REV. 1 (1985). 
government-issued permit. The government then sets a cap on the overall level of either pollution to be emitted by all sources in the aggregate, or resource exploitation to be allowed by all resource users in the aggregate. The government then distributes permits to sources or resource users. The total number of these permits is equal to the overall cap. The mechanism for distributing them may vary. The government may hold an auction or it may distribute permits to previous sources or users based on historic levels of pollution or resource use. But the important point-and what distinguishes these programs from traditional command-and-control regulations-is that the permits are tradable. That means any individual polluter or resource user can choose whether to: 1) simply keep her permits and emit pollutants or capture resources just up to the level allowed by her allotment of permits; 2) emit less pollution or capture less of the resource than her allotment of permits would have allowed and sell the unused permits for cash; or 3) buy more permits so as to be able to emit more pollution or capture more of the resource than her original allotment of permits would have allowed.

Thus, ETMs create markets in tradable permits, and the theory is that, as in any market, the permits will go to their most valued uses - or, in other words, end up in the hands of those who can make most efficient use of them. Accordingly, air pollution permits will go to those for whom pollution reduction is most expensive, while those for whom pollution is cheap will have an incentive to sell their permits for a profit. As a result, the overall costs for a given level of pollution reduction should fall. Similarly, individual fishing permits (known as Individual Transferable Quotas or ITQs) will go to the fishermen who can make the best use of them-those who are most efficient at catching fish. Because those fishermen spend less on fishing gear and labor to catch a given quantity of fish, they can afford to outbid others and buy ITQs at a higher price. Again, costs will be reduced. Less money will be expended catching the same number of fish. Thus, ETMs can-at least in theory-cut costs for a given level of pollution control or resource exploitation by answering the "allocation question." 97

The most prominent and well-known ETM currently in operation is the acid rain emissions trading program under the

97. See supra note 22 and accompanying text. 
1990 Clean Air Act, in which coal-fired power plants trade allowances for the emission of sulfur dioxide, a precursor to acid rain. ${ }^{98}$ But, other examples abound. EPA's Clean Air Interstate Rule sets up a series of trading programs for limiting emissions of nitrogen oxides and sulfur dioxide in the eastern United States. ${ }^{99}$ Various programs for the reduction of greenhouse gas emissions rely heavily on emissions trading mechanisms. 100 A number of states have experimented with water pollutant trading programs, and the EPA has recently issued guidance for those programs. ${ }^{101}$ ITQ programs operate in a number of commercial fisheries throughout the world to limit catch levels. ${ }^{102}$ The EPA and the Army Corps of Engineers have authorized the use of wetlands mitigation banking under section 404 of the Clean Water Act. 103 And habitat conservation banking is increasingly being used by landowners seeking permits under the Endangered Species Act. 104

My purpose here is not to judge the merit of these pro-

98. See 42 U.S.C. $\S \S 7401-7671$ (q) (2000).

99. See Rule to Reduce Interstate Transport of Fine Particulate Matter and Ozone (Clean Air Interstate Rule), 70 Fed. Reg. 25,162-25,405 (May 12, 2005).

100. See generally Richard B. Stewart, James L. Connaughton \& Lesley C. Foxhall, Designing an International Greenhouse Gas Emissions Trading System, 15 NAT. RESOURCES \& ENV'T. 160 (2001). The Regional Greenhouse Gas Initiative (RGGI), which is in the early stages of implementation by a coalition of northeastern states in the U.S. uses an emissions trading scheme. See RGGI website, available at http://www.rggi.org/. The European Union's Emissions Trading Scheme for the reduction of greenhouse gas emissions, has been in operation since 2005. See European Climate Exchange website, available at: http://www. europeanclimateexchange.com/index_flash.php.

101. See generally Water Quality Trading Policy, Issuance of Final Policy, 68 Fed. Reg. 1608 (Jan. 13, 2003).

102. See Grafton et al., supra note 92 , at 679 (study of ITQ system in British Columbia Halibut fishery); Rieser, supra note 8, at 408 (citing use of ITQs in four U.S. fisheries); Wyman, supra note 92, at 152-227 (case study of ITQs in U.S. coastal fisheries); see generally NATIONAL RESEARCH COUNCIL, SHARING THE FISH: TOWARD A NATIONAL POLICY ON INDIVIDUAL FISHING QUOTAS (1999); John H. Annala, New Zealand's ITQ System: Have the First Eight Years Been a Success or a Failure?, 6 REVS. IN FISH BIOLOGY \& FISHERIES 43 (1996).

103. See generally Federal Guidance for the Establishment, Use and Operation of Mitigation Banks, 60 Fed. Reg. 58,605 (Nov. 28, 1995); James Salzman \& J. B. Ruhl, 'No Net-Loss'-Instrument Choice in Wetlands Protection, in Moving To MARKETS IN ENVIRONMENTAL REGULATION: TWENTY YEARS OF EXPERIENCE (Jody Freeman \& Charles Kolstad eds., 2005), available at http://ssrn.com/abstract= 796771.

104. See generally Guidance for the Establishment, Use and Operation of Conservation Banks, 68 Fed. Reg. 24,753 (May 8, 2003); J.B. Ruhl, Alan Glen, \& David Hartman, A Practical Guide to Habitat Conservation Banking Law and Policy, 20 NAT. RESOURCES \& ENV'T. 26 (2005). 
grams. My concern is rather that these programs are too often mislabeled as real-world examples of the privatization solution to the tragedy of the commons. This mischaracterization creates the false impression that privatization solutions to commons problems are feasible and that we can ultimately dispense with government regulation. This false impression lends credence to the radical policy prescriptions of the free market environmentalists, which, as I argue in Part III, are intellectually incoherent.

Recall from Part I.C.1 that the most important distinction between the government regulation and privatization solutions to the tragedy of the commons has to do with who answers the "how much" question: under government regulation, the government answers it; under privatization, the market answers it. The obvious problem with categorizing ETMs as a privatization solution, then, is the fact that under these programs, it is clearly the government rather than the market that answers the "how much" question. Specifically, the government answers the "how much" question by setting the overall cap on pollution or resource use. 105

Because ETMs leave the "how much" question to government, these are not true markets in the welfare economics sense. 106 They do not produce outcomes that maximize overall social welfare. 107 This is because they only have the capacity to achieve one of the two functions that true markets normally perform. They can achieve allocative efficiency for a predetermined level of pollution or resource use, but they do not produce productive efficiency.

In a perfectly competitive market with no externalities, the

105. See Krier, supra note 61 , at 327 (1992). The government's role in monitoring and enforcing ETMs is also crucial and nontrivial. While, in theory, this is simply part of the definition and enforcement role that even the free market environmentalists concede government must play in any private property regime, in this context, that role tends to be significantly more expensive than in traditional private property contexts. It is far more difficult and expensive for the government to determine whether a power plant is emitting pollutants in excess of its allowances than it is to determine whether someone has trespassed on another's land. Indeed, unlike in the private land context, the market produces significant disincentives for private reporting of this kind of information on emissions levels. See generally Wendy E. Wagner, Commons Ignorance: The Failure of Environmental Law to Produce Needed Information on Health and the Environment, 53 DUKE L.J. 1619 (2004).

106. See BROMLEY, supra note 28 , at 38 .

107. Cf. Salzman \& Ruhl, supra note 91 , at 622 (arguing "[t]he basic goal in any trading system is to move toward a pareto-efficient outcome .....). 
"efficient" or welfare maximizing outcome is a function of supply and demand. As outlined in Part I.A, the market naturally reaches a Pareto efficient equilibrium at the point at which the supply and demand curves cross-that is, at the price and level of production at which marginal consumer willingness to pay no longer exceeds the marginal cost of production. This is the level of production at which consumer surplus (satisfaction of consumer preferences) and producer surplus (profits) are maximized and, therefore, where overall social welfare is maximized.

In an ETM "market," however, the supply and demand curves are not a direct function of consumer preferences and production costs as they are in a true (welfare maximizing) market. While the demand for a consumer good, like potato chips, depends on how many people like potato chips and how much they are willing to pay for them, the demand for a permit, quota, or allowance under an ETM has nothing to do with how much individuals like, are willing to pay for, or derive satisfaction from having permits, quotas, or allowances in the abstract. Rather, it is a function of where the government has set the overall cap. Firms have neither "preferences" for permits nor any intrinsic desire to reduce pollution levels in the absence of government-set limits on pollution. Their willingness to pay or preference for permits is driven by how many permits each firm is allocated and, therefore, how many additional permits each firm needs in order to comply with regulatory requirements. ${ }^{108}$ Where the cap is high, many firms will be able to meet regulatory requirements without purchasing additional permits, and demand will therefore be low. ${ }^{109}$ Where the cap is low, many firms will need to purchase additional permits, and demand will be high. ${ }^{110}$ Thus, the equilibrium point reached by an ETM is based on an artificial demand curve. Because it is not in any way tied to individual preferences-the measure of value in welfare economics-it has no relationship to overall social welfare or efficiency. ${ }^{111}$

108. Demand is also a function of the costs of pollution control. Where pollution control costs are low, many firms will be able to meet regulatory requirements simply by reducing emissions without having to buy permits. Where pollution control costs are high, more firms will want to buy permits.

109. Assuming the costs of production-or here, pollution control-are constant, low demand will translate to low prices.

110. Assuming constant pollution control costs, the price will be high.

111. See Yandle \& Morriss, supra note 93, at 161 ("[In ETMs,] [r] egulation in- 
Similarly, the supply curve in an ETM is artificially skewed by the government-set cap. To be sure, the supply curve is determined in part by production costs. Thus, the number of pollution control permits, for example, that firms will offer for sale on the market will in part depend on the costs of pollution control (the "production costs" of clean air). And those costs are what would determine the supply curve in a true market for clean air. But, in an ETM, the supply curve is also significantly affected by another factor that may have no relevance to social welfare - the level at which the government sets the cap. ${ }^{12}$ The cap determines how many permits each firm gets initially and, therefore, how many permits each firm will be able to make available for sale. ${ }^{113}$ The supply curve, then, while based in part on factors relevant to social welfare (pollution control costs), is nonetheless artificially distorted by the government-set cap.

The fact that, under an ETM, supply and demand are driven by artificially set caps rather than subjective consumer preferences means that the market equilibrium has little or no relationship to the true value to society of the resource at issue. Thus, the price at which an allowance trades under the acid rain program does not reflect the value of a ton of sulfur dioxide emissions to society in any real sense. It does not reflect the actual harm caused by a ton of sulfur dioxide in the atmosphere, nor does it reflect the amount of money that all people in the aggregate would be willing to pay to avoid that harm. Rather, it simply reflects the level at which the government has decided to set the overall cap on sulfur dioxide emissions.

A true market that actually maximized social welfare

duces scarcity and determines the potential for gains from trade, but the utilitarian basis for the value is uncertain at best.").

112. If the government were to use a perfect cost-benefit analysis (CBA) to set the cap, then, arguably, the cap would be relevant to social welfare. But, the government need not, and arguably cannot actually use such a criterion to set the cap. Indeed, I have argued elsewhere that a perfect CBA, or even a reasonable approximation thereof, is impossible. See Sinden, Cost-Benefit Lite, supra note 31, at 205-28; Sinden, In Defense, supra note 31, 1423-30, 1452-59.

113. The relationship between the supply curve for an ETM and the government-set cap is not a direct one (as it might seem at first glance). The relevant supply of permits for purposes of constructing a supply curve is not the total number of permits issued by the government, but rather the number offered for sale by permit holders. This number is certainly affected by the total number issued, but it is also a function of other factors, like pollution control costs, as discussed above. 
would have to take into account the subjective preferences of all those affected by sulfur dioxide pollution. This would be a market in which reductions in sulfur dioxide emissions were sold by polluters and jointly purchased by the group of people affected by the pollution. In this version of Coasian bargaining, the market would reach a welfare maximizing equilibrium at the point where the supply and demand curves crossed-that is, where the marginal costs of pollution control equaled the marginal consumer willingness to pay for pollution reductions. This point would produce the level of pollution reduction that maximized overall social welfare and a price for pollution reductions that actually reflected their value in terms of consumers' willingness to pay for cleaner air.

The problem, of course, is that this market would fail to reach a truly welfare maximizing equilibrium unless every person who is affected by sulfur dioxide pollution, no matter how incrementally, was involved in the purchase of pollution reductions. Given that air pollution involves such individually small harms spread diffusely among such large groups of people and that public knowledge about the harms caused by air pollution is so imperfect, collective action problems, information problems, and other transaction costs doom any attempt to create such a market in the real world. Because these problems would prevent most of those "consumers" with a preference for clean air from actually participating in the market, any such real-world version of a market for clean air would vastly underproduce clean air.

Actually, under the Clean Air Act's existing sulfur dioxide emissions trading program, individuals or groups wishing to see the overall level of sulfur dioxide emissions reduced can purchase allowances and "retire" them (take them out of the market). To that extent, it arguably has the capacity to function as a kind of real-world version of the true market for clean air described above. The problem, of course, is that monumental transaction costs and collective action problems make it inevitable that far fewer retirement purchases occur than would be efficient (or welfare-maximizing). ${ }^{114}$

114. In addition to the transaction-cost problem, this market also fails to replicate the "true" market I describe above because it begins with a government-set cap on overall pollution levels. While the market has the capacity to reduce overall levels of pollution below the cap, it does not have the capacity to increase them above the cap. This is not a problem if the cap is set too high. Retirement pur- 
The valuation problem-the fact that the market price for a permit or allowance under an ETM is a function of artificial, government-controlled supply and demand curves rather than subjective consumer preferences-becomes particularly apparent in ETMs that trade in non-fungible commodities. James Salzman and J.B. Ruhl have called these "currency" problems. ${ }^{115}$ Thus, wetlands mitigation banking schemes, for example, tend to use acres as the "currency" of value in evaluating wetlands trades. Yet, an acre of natural wetlands in one location and an acre of artificial wetlands in another location may not be at all equivalent in terms of the social benefits they provide. The familiar phenomenon of "hot spots" that arises in emissions trading schemes is an example of this larger problem. ${ }^{116}$

At one level, this is simply a problem of regulatory design: a wetlands mitigation banking program that authorized trades based on equivalency of function and value rather than acreage would avoid the problem-though, as Salzman and Ruhl point out, fine calibrations of this sort can complicate the process and inhibit trading. ${ }^{117}$ On another level, however, this problem appears as a problem only because of a deeper conceptual mistake: the mischaracterization of ETMs as true markets in a welfare economics sense. If we instead recognize that ETMs are a form of government regulation, then it seems unremarkable that government will have to do some heavy lifting in order to measure the relative social values of the commodities or resources at issue (for example, to measure the relative values and functions of different wetlands). It is only when we (erroneously) conceptualize ETMs as true markets that we expect them to spontaneously and accurately value commodities without government help. After all, the magic of true markets is that they do exactly that. Through innumerable voluntary transactions, the invisible hand of the market sets prices for commodities that reflect actual consumer preferences and production costs. A true market for wetlands would similarly price wetlands according to their costs of protection or produc-

chases will, in the absence of transaction costs, effectively reduce the cap to the efficient level. If the cap is set too low, however, the trading program will not have the capacity to increase the number of allowances and thereby raise the cap to the efficient level.

115. Salzman \& Ruhl, supra note 91 , at 612 .

116. See FREYFOGLE, THE LAND WE SHARE, supra note 27, at 191-93.

117. Salzman \& Ruhl, supra note 91 , at $637-38$. 
tion and the overall benefit they provide to society (the aggregate willingness to pay of all members of society). But wetlands mitigation banking, like other ETMs, is not a true market. It sets prices not according to consumer preferences but according to artificial supply and demand curves shaped by government regulation.

Part of the problem lies in the fact that the things traded in ETMs do not constitute ownership rights in discrete, identifiable portions of a resource itself. ${ }^{118}$ As a result, they lack a critical characteristic of resource ownership frequently touted as one of the most important aspects of private property/market systems: they do not encourage the holder of the permit, allowance, or quota to invest in the resource in order to maximize its value. ${ }^{119}$ An ITQ, for example, does not constitute an ownership interest in any particular fish. It is an abstract right to catch a certain number of fish (an option to catch some number of fish in the future), but the ITQ-holder has no way of knowing in advance which individual fish she will ultimately take. As a result, the ITQ-holder has no incentive to invest in any particular fish. If, for example, an ITQ holder were to throw a fish back in the water in hopes of increasing the yields for next year, she would have no guarantee that she would be the beneficiary of that increased yield. Accordingly, the ITQholder faces a typical tragedy-of-the-commons dynamic. While the cost associated with throwing back the fish will accrue solely to her, the benefit will be shared with the entire group. The same logic holds in other contexts as well. The owner of an air pollution allowance has no property right in the air resource itself and, thus, has no incentive to maximize the value of that resource by, say, cleaning up a certain piece of air space.

In sum, ETMs do not constitute a privatization solution to the tragedy of the commons, nor do they constitute a step in that direction. Characterizing them as such leads to miscon-

118. See David M. Driesen, What's Property Got to Do with It? (Mar. 11, 2003) (reviewing DANIEL COLE, POLLUTION \& PROPERTY: COMPARING OWNERSHIP INSTITUTIONS FOR ENVIRONMENTAL PROTECTION (2002)), http://ssrn.com/abstract= 387282 (suggesting that property rights concepts are not helpful in understanding emissions trading).

119. See ANDERSON \& LEAL, supra note 7, at 4. Many authors miss this point. See, e.g., Robert Stavins \& Bradley Whitehead, Market-based Environmental Policies, in THINKING ECOLOGICALlY: THE NEXT GENERATION OF ENVIRONMENTAL POLICY 105, 106 (Marian R. Chertow \& Daniel C. Esty eds., 1997) ("Market-based instruments [including ETMs] align the financial incentives of companies with environmental objectives."). 
ceptions about ETMs and about the efficacy of privatization solutions in general. ETMs are simply a form of government regulation and should be categorized accordingly.

\section{B. Water Markets}

Fresh water is a resource that is hard to pin down within fixed property boundaries and is, thus, particularly vulnerable to the tragedy of the commons. Indeed, in many parts of the world, wasteful water use practices are already leading to severe shortages. Over one billion people around the globe currently have no access to clean drinking water. ${ }^{120}$ In the arid states of the American West, water scarcity has become a problem of increasing urgency as urban development competes with well-entrenched agricultural uses for limited supplies. As construction of the large-scale dams and reservoirs that fueled the region's exponential growth in the twentieth century has become politically and environmentally infeasible, policymakers have begun to consider ways to more efficiently allocate existing supplies. ${ }^{121}$ In this climate, the idea of water markets is becoming increasingly popular. ${ }^{122}$ Water markets are fre-

120. See Maude Barlow \& Tony Clarke, Blue Gold: The Fight to Stop THE CORPORATE THEFT OF THE WORLD'S WATER xii, 24 (2002); Robert Glennon, Water Scarcity, Marketing, and Privatization, 83 TEX. L. REV. 1873, 1890 (2005).

121. See Glennon, supra note 120, at 1873-74 ("When we needed more water in the past, we built a dam, dug a canal, or drilled a well. With some exceptions, these options are no longer viable due to a paucity of sites, dwindling supplies, escalating costs, and environmental objections. Instead, we are entering an era in which demand for new water will be satisfied by reallocating and conserving existing sources."); Brian E. Gray, The Shape of Transfers to Come: A Model Water Transfer Act for California, 4 HASTINGS W.-NW. J. ENVTL. L. \& POL'Y 23, 25 (1996).

122. See Rodney T. SMITH, TRAdING Water: AN ECONOMIC AND LEGAL FRAMEWORK FOR WATER MARKETING 2-3 (1988); Glennon, supra note 120, at 1884-85; Gray, supra note 121, at 25-26. In 1971, a report by the National Water Commission authored by Professors Charles J. Meyers and Richard A. Posner argued for greater use of the market in the allocation of water resources. See CHARles J. MEYERS \& RichaRd A. POSNER, MARKET TRANSFERS OF WATER RIGHTS: TOWARD AN IMPROVED MARKET IN WATER RESOURCES 1-8 (1971) (National Water Commission Report \# NWC-L-71-009). In 1978, two reports in California, one commissioned by the governor and one by the legislature, strongly endorsed the creation of water markets in the state. See ELLEN HANAK, WHO SHOULD BE ALLOWED TO SELl WATER IN CALIFORNIA? THIRD-PARTY ISSUES AND THE WATER MARKET 3 (2003). The free market environmentalists are, of course, enthusiastic proponents of water markets. See, e.g., ANDERSON \& LEAL, supra note 7, at 89-105; TERRY L. ANDERSON \& PAMELA SNYDER, WATER MARKETS: PRIMING THE INVISIBLE PUMP 17-29 (1997); WATER MARKETING—THE NEXT GEN. 
quently discussed as though they constitute an example of the privatization solution to the tragedy of the commons. ${ }^{123}$ But, like ETMs, they are more appropriately categorized as a form of government regulation.

Although "water markets" are treated as a relatively new policy innovation, the common law has actually recognized private property rights in fresh water for centuries. In the American West, rights to surface water have traditionally been governed by the prior appropriation doctrine, which allocates rights to the use of surface water under the principle of "first in time, first in right." 124 Thus, water users along a particular stream or river are ranked from most senior to most junior depending on how far back in time each user can trace her claim. In times of drought, water is shut off to the most junior appropriators first. Additionally, under what is often termed the "use it or lose it" rule, rights holders must continuously use the full amount of water originally claimed or forfeit their right to the unused amount.

The common law treated these appropriative water rights as a form of property, and, in many states, they were transferable, even to other watersheds. 125 These property rights did

ERATION xi-xv (Terry L. Anderson \& Peter J. Hill eds., 1997).

123. See NATIONAL RESEARCH COUNCIL, WATER TRANSFERS IN THE WEST: EF. FICIENCY, EQUITY, AND THE ENVIRONMENT 3 (1992) ("Reliance on water marketing, as opposed to government subsidy and regulation, reflects a general societal belief that markets are a more effective way to allocate scarce resources to meet the twin goals of efficiency and equity."); Gray, supra note 121, at 24 ("Market allocation of resources, including water, is preferable to other systems of allocation, such as allocation by government planning and reallocation by government fiat. A free market for water would increase both the efficiency of the use of water and the efficiency of the allocation of water in California.").

124. Reed D. Benson, Maintaining the Status Quo: Protecting Established Water Uses in the Pacific Northwest, Despite the Rules of Prior Appropriation, 28 ENVTL. L. 881, 886 (1998). A number of western states also apply the prior appropriation doctrine to ground water withdrawals, though some apply the rule of capture. See Ben F. Vaughan IV \& Peter M. Emerson, Protecting the Edwards Aquifer: An Efficient and Ecological Alternative, in WATER MARKETING-THE NeXT GenERATION 167, 175-76 (Terry L. Anderson \& Peter J. Hill eds., 1997).

125. Transfers were allowed, for example, in California. See, e.g., McDonald v. Bear River \& Auburn Water \& Mining Co., 13 Cal. 220, 232-33 (1859) ("The ownership of water, as a substantive and valuable property, distinct, sometimes, from the land through which it flows ... may be transferred like other property."). In ten other states, water rights transfers were banned, however. See Barton H. Thompson, Jr., Water Markets and the Problem of Shifting Paradigms, in WATER Marketing-The NeXT Generation 1, 3 (Terry L. Anderson \& Peter J. Hill eds., 1997). Many states also restrict the export of water to other states, though the Supreme Court's decision in Sporhase v. Nebraska, 458 U.S. 941 (1982), may have 
not historically lead to the creation of active markets, however. This was primarily because the rules surrounding transfer made trading so cumbersome that transfers rarely occurred..$^{126}$ Moreover, many of the big, federally-operated water projects imposed additional layers of Byzantine bureaucratic requirements on top of the common law rules and sometimes even prohibited transfers outright. Accordingly, most proposals for stimulating water markets have focused on simplifying and expediting the transfer process in order to stimulate trading. ${ }^{127}$

The problem is that many of the cumbersome legal requirements surrounding the transfer of water rights stem at least in part from the unique nature of the resource and are therefore difficult to abandon entirely. Water flows across boundaries, seeps under the earth, evaporates into the air, and fluctuates drastically in quantity depending on random and unpredictable weather patterns. As such, water is not amenable to the imposition of full ownership rights in the nature of a fee simple interest in land. ${ }^{128}$ Water rights tend instead to be usufructuary-they confer a use right rather than permanent

cast some doubt on the legality of some of these restrictions. See James L. Huffman, Institutional Constraints on Transboundary Water Marketing, in WATER MARKETING-The NeXT Generation 31, 35-36 (Terry L. Anderson \& Peter J. Hill eds., 1997); Thompson, supra at 19-20. In contrast to the western regime, under the riparian rights approach prevalent in the eastern states, water rights cannot be transferred separately from the riparian land to which they are appurtenant. See BRENT M. HADDAD, RIVERS OF GOLD: DESIGNING MARKETS TO AlLOCATE WATER IN CALIFORNIA 6 (2000).

126. See Joseph L. Sax, Understanding Transfers: Community Rights and the Privitization of Water, 1 HASTINGS W.-NW. J. ENVTL. L. \& POL'Y 13, 15 (1994); HADDAD, supra note 125 , at 30 .

127. But see Thompson, supra note 125, at 6 (arguing that there are "more significant obstacles" to trading than cumbersome transfer rules, "includ[ing] inconsistent legal paradigms, opposition by governmental agencies that control much of the water and key transportation facilities, and to a growing extent, concerns about the impact of transfers on exporting communities").

128. See HADDAD, supra note 125, at 21; Bonnie G. Colby, Regulation, Imperfect Markets, and Transaction Costs: The Elusive Quest for Efficiency in Water Allocation, in HANDBOOK OF ENVIRONMENTAL ECONOMICS 475, 477 (Daniel W. Bromley ed., 1995); Sax, supra note 126, at 13 ("Unlike almost every other form of property, which we allow to be entirely privatized, water has always been viewed as something in which the community has a stake and which no one can fully own."). The free market environmentalists, of course, take a different view. See, e.g., ANDERSON \& SNYDER, supra note 122, at 105 ("The belief that the doctrine of [prior] appropriation contains a great deal of potential for market failure is pervasive but largely unfounded."); Huffman, supra note 125, at 34 ("There are . . . no sound theoretical reasons for drawing a distinction between water rights and other interests in property."). 
ownership. Thus, after the holder of a water right uses her allotment, much of it may be returned to the stream in the form of "return flows," which are in turn used by the next waterright holder downstream. 129 Because of this usufructuary nature of water rights, they are accompanied by particularly extensive and significant externalities. One right holder's diversion of surface water can have important impacts on downstream users. ${ }^{130}$ The importance of these externalities was recognized early on by the common law, which imposed two doctrines aimed at minimizing them. The beneficial use rule requires that water rights be put to "beneficial use"-i.e., that water not be wasted. ${ }^{131}$ Additionally, the third-party effects rule requires consideration and mitigation of potential impacts on other water rights holders before a transfer can take place. ${ }^{132}$

The third-party effects rule is administered differently in different states, many of which have now incorporated it into a set of administrative procedures governed by statute. ${ }^{133}$ But, in most instances, the procedure follows the same general form. ${ }^{134}$ A person seeking to transfer a water right must file an application with a state water agency. This permit triggers the provision of public notice to all interested parties. Other rights holders adversely affected by the proposed transfer can then file a formal protest. Ultimately, if a negotiated settlement is

129. See SMITH, supra note 122 , at 12 ("Most surface water is 'reused' many times by different users.").

130. Similarly, one person's withdrawal of groundwater can affect the abilities of others to withdraw from the same aquifer. See id.

131. See CAL. ConST. art. X, § 2; Joslin v. Marin Mun. Water Dist., 429 P.2d 889, 895 (Cal. 1967).

132. See Scott v. Fruit Growers' Supply Co., 258 P. 1095, 1097 (Cal. 1927) (noting that appellant could not divert water from a creek tributary so as to deprive appellee of water rights because such a change would "interfere with the rights of others [to use the water] . . .."); Butte T.M. Co. v. Morgan, 19 Cal. 609, 615 (1862) (transfer of water rights "must not be to the prejudice of the rights of others."). This protection of the interests of third parties was later codified by statute. See CAL. WATER CODE $§ \S 1702,1706$ (2006). In California, additional barriers to water trading are also created by the public trust doctrine, see Nat'l Audubon Soc'y v. Superior Court, 658 P.2d 709, 721 (Cal. 1983) ("[T] he public trust doctrine . . . protects navigable waters from harm caused by diversion of nonnavigable tributaries."), and county-of-origin protections, see CAL. WATER CODE $\S \S 10505,10505.5$ (2006).

133. See, e.g., Oregon Rev. Stat. Ann. $\S 540.520$ (2006); Utah Code Ann. $\S 73-3-3(2006)$.

134. See Barton H. Thompson, Jr., Institutional Perspectives on Water Policy and Markets, 81 CAL. L. REV. 671, 703 (1993). 
not reached between the transfer applicant and the protester, the state agency holds a hearing and rules on the application, denying the transfer, allowing the transfer, or allowing it subject to certain conditions, such as payment of restitution to injured third parties. 135

Thus, from the beginning, the common law recognized that property rights in water were not of the kind that could solve commons problems by internalizing all externalities within property boundaries (i.e., my "private property solution"). One party's use right in the same water that will subsequently flow downstream to be subject to another party's use right will inevitably involve externalities-literal "spillover" effects. The third-party effects rule and the beneficial use rule acknowledged the inevitability of these externalities.

In theory, one might view the third-party effects rule as the common law's attempt to implement what I have called "the market solution" to the inevitable externalities that accompany water rights. The third-party effects rule essentially created an institutionalized forum for a kind of Coasian bargaining to take place between the affected parties. The problem is that in the real world, such bargaining rarely took place, and when it did, it involved only downstream rights holders, who were usually only a small fraction of the people actually impacted by the environmental effects of water transfers. Thus, the third-party effects rule did not foster true Coasian bargaining both because it failed to bring all interested parties to the bargaining table and because it imposed such high transaction costs on those it did bring to the table.

Today, the externality problem looms even larger. Changing values and improved scientific understandings of the crucial role that water plays in maintaining species habitat and ecosystem functioning have expanded the universe of externalities associated with water use substantially. ${ }^{136}$ In particular, there is now widespread recognition of the importance of maintaining instream flows, although the legal mechanisms necessary for such maintenance are still lacking in many states. ${ }^{137}$

135. See Colby, supra note 128 , at 479 .

136. See Eduardo Bautista \& Edward McBean, Effects of Water Marketing on Physical and Biological Resources, in SHARING SCARCITY: GAINERS \& LOSERS IN WATER MARKETING 57 (Harold O. Carter, Henry J. Vaux, Jr. \& Ann F. Scheuring eds., 1994).

137. See Bonnie Colby Saliba \& David B. Bush, WATER Markets In Theory and PRACTICE: Market Transfers, Water VAlues, AND PUBlic POLICY 74-77 
Additionally, in recent decades, there has been an increasing recognition of the social and economic effects that water transfers can have on local farming communities. ${ }^{138}$ Accordingly, water law in the western states is gradually changing to require consideration of environmental and community impacts in addition to impacts on the existing water rights of third parties. 139

Thus, while efforts to create water markets focus on removing the barriers to trading, they also recognize the importance of accounting not only for third-party effects, but for the broader ecological and community impacts that have recently been recognized as valuable. Accordingly, all such efforts retain some procedure for the approval of water rights transfers by some government entity based on the consideration of external effects. ${ }^{140}$ And rather than simply facilitating bargain-

(1987). Water use also affects water quality. See Charles W. Howe, Increasing Efficiency in Water Markets; Examples from the Western United States, in WATER MaRketing-The NeXT Generation 79, 93 (Terry L. Anderson \& Peter J. Hill eds., 1997).

138. Studies have shown that the economic effects of transfers on local communities can be significant. See Charles W. Howe, Jeffrey K. Lazo, \& Kenneth R. Weber, The Economic Impacts of Agriculture-to-Urban Water Transfers on the Area of Origin: A Case Study of the Arkansas River Valley in Colorado, 72 AM. J. AGRIC. ECON. 1200, 1203 (1990). See also Richard E. Howitt, Effects of Water Marketing on the Farm Economy, in SHARING SCARCITY: GAINERS \& LOSERS IN WATER MARKETING 97 (Harold O. Carter, Henry J. Vaux, Jr. \& Ann F. Scheuring eds., 1994).

139. See, e.g., Nat'l Audubon Soc'y v. Superior Court, 658 P.2d 709, 712 (Cal. 1983) (requiring state to consider public trust values of navigation, fisheries, and environmental impacts in assessing water transfers). See also Howe, supra note 137, at 92 . There has been an increasing movement in favor of including consideration of area-of-origin impacts in the transfer approval process. See NATIONAL RESEARCH COUNCIL, supra note 123, at 115-16, 208-09; Thompson, supra note 125, at 21-22. California, for example, has enacted county-of-origin protection statutes. See Lawrence J. MacDonnell \& Charles W. Howe, Area-of-Origin Protection in Transbasin Water Diversions: An Evaluation of Alternative Approaches, 57 U. COLO. L. REV. 527, 532-33 (1986). Although not all of the interests affected by water transfers have yet gained formal recognition in the law, as Brent Haddad has pointed out, "both formal and informal avenues of recourse exist, and many proposed transfers have been blocked in part by parties who were not formal holders of water rights." HADDAD, supra note 125 , at 7.

140. See HADDAD, supra note 125 , at $141-48$ (recommending with regard to the creation of a water market in California that one must "[h]old [p]arties to a [p]roposed [w]ater [t]ransfer [a]ccountable to [o]ther [i]nterested [p] arties in the [s]tate"); SMITH, supra note 122, at 74 ("Policy, economic, and political considerations will preclude water markets from functioning without consideration of legitimate third-party interests."); Glennon, supra note 120, at 1902 (advocating government protection for third party interests and environment in design of water markets); Gray, supra note 121, at 39-42 (urging society to "expand the exist- 
ing between transferors and third parties as the old third-party effects rules did, these new systems have to acknowledge the new reality of ecological and community impacts. This set of externalities affects such large and diffuse groups of people that collective action problems and other transaction costs render Coasian bargaining impracticable. ${ }^{141}$ Accordingly, when ecological and community impacts are added to the mix, the government's role in approving trades must necessarily shift from one of simply facilitating bargaining among affected parties to making substantive judgments about the level of impact that is acceptable or desirable. ${ }^{142}$

In other words, requiring review of water rights transfers based on ecological and community impacts puts the government squarely in the role of answering the "how much" question. Once the government takes on that role, the market is no longer "free."143 Market dynamics and the resulting allocation of water are no longer dictated solely by the individual preferences of market participants. Instead, they are shaped, at least in part, by government policy as expressed through the restrictions placed on trades from the application of criteria relating to ecological and community impacts. ${ }^{144}$ Thus, in the final

ing protections for third party interests" via a model statute designed to stimulate active water market); Howe, supra note 137, at 83 ("Environmental effects . . must be incorporated in water transfer decisions."). Several authors have noted the tension between the desire to foster a robust market while at the same time protecting third party and environmental interests. See HADDAD, supra note 125, at 133-34 ("Throughout the twentieth century, California's water policy moved away from strong private-property rights and toward greater public participation in decisions about water use and water allocation. . . Today's efforts to create a statewide water market run contrary to the twentieth century's evolution of property rights in water."); HANAK, supra note 122, at 4.

141. See HADDAD, supra note 125 , at 29 (explaining the free rider and other transaction cost problems that prevent environmental groups from participating in water transfer negotiations).

142. Under the Model Water Transfer Act for California, for example, the State Water Resources Control Board may not approve a water transfer unless it first makes an affirmative finding that the transfer "would not unreasonably affect fish, wildlife, or other instream beneficial uses." Gray, supra note 121, at 51. Additionally, where water is to be transferred to another county, the Board must find that the proposed transfer would not "cause substantial harm to the economy in the area from which the water is to be transferred." Id.

143. See Colby, supra note 128, at 483 (nowhere in the American west can water transfer systems be described as a "free market").

144. It may be that-in the parlance of Carol Rose's "theoretical property story"-water has taken on more of the characteristics of a public good in the western United States in recent years as awareness of environmental and community impacts has grown, thus, making appropriate a collective management 
analysis, because of the inevitable government role in accounting for third-party effects and other externalities, water markets must be categorized as a government regulation rather than a privatization solution to the tragedy of the commons. ${ }^{145}$

Indeed, where governments impose instream flow requirements-as they increasingly do-those requirements essentially serve the same function as the overall catch limit associated with an ITQ or the "cap" in an emissions trading program. ${ }^{146}$ In a similar vein, markets for groundwater have been proposed that would annually set a minimum "safe yield" (a cap on overall withdrawals from the aquifer), allocate percentage shares in that yield to individual water users, and then allow those shares to be traded. ${ }^{147}$ By imposing instream flow or safe yield requirements, government answers the "how much" question, just as it does when it sets a cap or a catch limit under an ETM. As in other ETM contexts, the existence of pervasive externalities prevents a "free market" from answering this question correctly. By setting a cap or an instream flow level, the government removes that critical responsibility from the market and answers the "how much" question itself, leaving to the market only the secondary task of "answering the allocation question." 148

The mischaracterization of ETMs and water markets as privatization solutions to the tragedy of the commons is on one level simply a semantic mistake. But, it is a semantic mistake that has significant and potentially damaging ramifications for the substantive debate. Characterizing these forms of government regulation as examples of the privatization solution to the

scheme rather than a regime of private rights. See Carol M. Rose, Energy and Efficiency in the Realignment of Common-Law Water Rights, 19 J. LEGAL STUD. 261, 290-93, 295 (1990).

145. See Dellapenna, supra note 11 , at 372 . Water banks are also not free markets because the government usually sets the price rather than allowing it to fluctuate with supply and demand. See Thompson, supra note 125, at 8-9 ("The banks bear little resemblance to a free market."). A system that required government to ensure the protection of ecological values by buying rights to instream flows might look a little more like a free market. Government would essentially be representing the interests of all those who were prevented by transaction costs from being directly involved in the bargaining. It is doubtful, however, that government would be able to raise enough tax money to buy the economically efficient amount of water for instream flows.

146. See HADDAD, supra note 125, at 36 (endorsing idea of government-set "cap" on water markets).

147. See Vaughan \& Emerson, supra note 124, at 177-83.

148. See supra note 22 and accompanying text. 
tragedy creates the impression that such solutions are in fact possible and thereby inadvertently lends credence to the outlandish claims of the free market environmentalists. The blatantly ends-driven, ideological claims of the free marketeersthat government regulation of environmental problems can be dispensed with in all sorts of arenas and replaced with a regime of private property rights-have long been dismissed as occupying the extreme fringe of the environmental policy debate. In recent years, however, as the center of political power has moved to the right, these fringe voices have gained increasing influence over mainstream policy makers. For example, with the election of George W. Bush to the presidency in 2000, Terry Anderson-author of the book Free Market Environmentalism and perhaps the principal spokesperson for the most extreme version of this view-went from being a largely ignored fringe ideologue to a personal advisor to the president. ${ }^{149}$ In this climate, policy prescriptions that were once widely dismissed are being accorded increasing legitimacy. The 109th Congress, for example, saw the introduction of several bills that would have authorized the sale of federal public lands to private parties, one of the central policy goals advocated by the free marketeers. ${ }^{150}$ And President Bush's 2007 budget proposal to Congress sought to raise a billion dollars in federal revenue by selling off over 300,000 acres of federal public lands. ${ }^{151}$

The next Part will examine various privatization regimes involving land, ocean resources, and wildlife that have been promoted by the free marketeers and others as privatization solutions to the tragedy of the commons.

149. See Mark Hertsgaard, Trashing the Environment: Kyoto Was Just a Start for Bush, THE NATION, Feb. 3, 2003, at 15; see also ANDERSON \& LEAL, supra note 7.

150. In November, 2005, Congressman Richard Pombo of California inserted a measure into the House budget bill that would have amended the 1872 Mining Law to authorize the sale of millions of acres of federal public lands to mining companies and other private parties for development. See Robert McClure, Bill Would Open Public Land, SeatTle Post-InTELligencer, Nov. 12, 2005, http:// seattlepi.nwsource.com/local/248143_mining12.html. The provision was ultimately withdrawn after a public outcry. See NPR, Elizabeth Shogrun, Protests End Plan to Sell Federal Lands for Mines, Dec. 18. 2005, available at http://www. npr.org/templates/story/story.php?storyId $=5060323$.

151. Bush Budget Would Sell Land to Raise \$1 Billion, MSNBC, Feb. 13, 2006, http://www.msnbc.msn.com/id/11257181/. 


\section{THE APPLICATION MistAKE}

Land is the prototypical example of private property, and many moderate voices (including Garrett Hardin himself) have claimed that, at least in some contexts, private land ownership can provide a privatization solution to the tragedy of the commons. On close inspection, it becomes clear that these claims are based on an erroneous set of assumptions. But, as with ETMs and water markets, the concern is not so much these claims themselves, which are modest in scope, but the aura of legitimacy they create for the more outlandish proposals of the free marketeers, who argue that the privatization of national parks and other federal lands, as well as ocean resources and wildlife, can successfully solve all the commons problems associated with these resources.

While the private property regimes examined in this part are, like ETMs and water markets, mistakenly described as privatization solutions to the tragedy of the commons, this discussion differs from that in Part II. This time the mistake is not conceptual. The regimes examined below could conceivably provide a privatization solution to the tragedy given an idealized set of circumstances in a hypothetical world. The problem comes in the application of the conceptual framework to the conditions likely to exist in the real world. In each of the three contexts examined below-land, oceans, and wildlife-the dynamics of ecological degradation make it impossible to achieve in practice even a reasonable approximation of the set of ideal conditions necessary to make either a private property or a market solution succeed.

\section{A. Land}

Land is the archetypal form of private property. The idea of land ownership evokes romantic notions of self-sufficiency, independence, and security that feed the passions of the property rights and wise-use movements. ${ }^{152}$ Land is also where the privatization solution to the tragedy of the commons began. We can, after all, easily envision Garret Hardin's cattle herders improving their collective destiny by dividing their common pasture into private parcels. Unlike some other natural re-

152. See FREYFOGLE, BOUNDED PEOPLE, supra note 74, at 91-113. 
sources, land stays put and is amenable to the construction of permanent boundary markers. Accordingly, it is the prototype for conceptualizing the private property solution to the tragedy of the commons.

These factors may also explain why privatization of land ownership is also high on the agenda of the free market environmentalists. ${ }^{153}$ They repeatedly cite the late-nineteenthcentury privatization of common rangelands in the American west as an example of a private property ownership regime solving a real-world tragedy of the commons. ${ }^{154}$ A top priority on the free market environmentalists' current public policy agenda is the privatization of the remaining federally owned lands in the United States. ${ }^{155}$

Because private land ownership seems so natural and so easy to conceptualize, land seems like an obvious place to im-

153. See Anderson et al., supra note 73, at 18 ("The surface boundary of land tracts is sufficient in most circumstances to provide well-defined property rights . ..").

154. See, e.g., ANDERSON \& LEAL, supra note 7, at 29-31; Terry L. Anderson \& P. J. Hill, The Evolution of Property Rights: A Study of the American West, 18 J. L. \& ECON. 163, 172 (1975); see also Ellickson, supra note 40, at 1330.

155. See, e.g., ANDERSON \& LEAL, supra note 7, at 74, 179-83; Anderson et al., supra note 73 , at 1,14 (offering "a blueprint for auctioning off all [U.S.] public lands over 20 to 40 years" including "all BLM, Forest Service, National Park, National Monument, National Recreation Area, continental shelf, deep sea bed, and military lands . . . ."); see also James L. Huffman, The Inevitability of Private Rights in Public Lands, 65 U. CoLO. L. REV. 241, 245 (1994) ("[U]ltimately, only private interests exist, whether the lands are owned privately or by the federal government."). These arguments mirror those that were made in the 1970 s and early 1980 s and unsuccessfully pushed by President Reagan in the early years of his presidency. See ROBERT H. NELSON, PUblic LandS AND PRIVATE RIghtS: The Failure of Scientific Management 183-99 (1995); John Baden, Privatizing Wilderness Lands: The Political Economy of Harmony and Good Will, in PRIVATE RightS \& PUBLIC LANDS 53, 54 (Phillip N. Truluck ed., 1983); Richard Stroup \& John Baden, Externality, Property Rights, and the Management of Our National Forests, 16 J.L. \& ECON. 303, 305 (1973). Such proposals remain politically unpalatable, at least with respect to the national parks, as evidenced by the recent flap over a proposal by Representative Richard Pombo to sell off fifteen national parks. See Eric M. Weiss, Document Causes Roosevelt Island Uproar, WASH. PosT, Sept. 27, 2005, at B2. The free market environmentalists' argument that privatization of federal lands will solve commons problems better than either public ownership or government regulation is distinct from a more moderate argument made by some others that while government regulation is necessary to address externality problems, some federal lands should be privatized (and subject to government regulation). See, e.g., NELSON, supra, at 219-24, 237-40. The question of whether, given adequate government regulation, private or public ownership of federal lands would be better is beyond the scope of this paper, though I will note that the Takings Clause could pose impediments to adequate regulation of privatized lands. 
plement the privatization solution to the tragedy of the com. mons. But can private land ownership actually operate as a solution to the tragedy in the real world? Answering this question requires consideration of the criteria developed in Part I.

\section{The Myth}

In a landmark article, Robert Ellickson analyzed the question whether private property regimes or government regulations are best suited to efficiently organizing land use. ${ }^{156} \mathrm{He}$ developed a typology that divides land use activities into three types depending on their scope of impact: small, medium and large. He argued that where small and medium activities predominate, individual private property ownership is the most efficient arrangement, while large activities may call for government regulation. ${ }^{157}$

Small events are those that only impact the individual landowner. Ellickson offers as an example the cultivation of a garden of tomato plants. ${ }^{158}$ These, then, are events that produce no effects that extend beyond the boundaries of the individual parcel and, thus, allow what I am calling the private property solution to operate.

Medium events are those that affect only a small group of neighbors. Ellickson offers as an example the construction of a small dam, which he posits will only affect one neighbor. ${ }^{159}$ The assumption is that with only a small number of people affected, transaction costs will be low and Coasian bargaining will be feasible. ${ }^{160}$ Thus, medium events allow what I am call-

156. See generally Ellickson, supra note 40.

157. See id. at 1331, 1334-35 (Noting that "for activities that result in mostly small and medium events, individual ownership is better than both open-access and group ownership for minimizing the sum of deadweight losses and transaction costs," while a "governing body . . . might be able to respond to [a] . . large event much more expeditiously than . . . [a] diffuse group of individual[s]"); see also Hsu, supra note 45, at 853-54.

158. See Ellickson, supra note 40, at 1327.

159. See id. at 1334-35.

160. See id. at 1330-31. Ellickson also argues that private property ownership in the context of medium events creates informational efficiencies because it "relegates the settlement of disputes . . . to those persons most likely to be informed about the matter in controversy." Id. at 1331. But this ignores the fact that even externalities affecting only a small number of people may often require specialized and expensive scientific knowledge to resolve. In such circumstances, the economies of scale to be gained through a system of government regulation that centralizes the generation of such knowledge can be quite significant. The scientific is- 
ing the market solution to function.

Large events are those that affect a large number of people. Ellickson offers air pollution as an example. In these situations, there are clearly external effects extending beyond the boundaries of the individual property owner's parcel, and the large number of people affected renders transaction costs prohibitive of a Coasian solution. In these circumstances, Ellickson acknowledges that government regulation or a common ownership regime may be preferable to a privatization solution.

The problem is not Ellickson's typology itself nor the conclusions he draws from it in the abstract, which are perfectly logical. Rather, the problem lies with his assumptions about how this typology will apply in the real world. Ellickson clearly assumes that the majority of land use activities will produce only small and medium events and that unregulated private property regimes should therefore be the rule, rather than the exception. ${ }^{161}$ In fact, however, Ellickson's assumptions betray a naivete about the realities of ecological degradation. As we become increasingly aware of the vast web of connections that link species and ecosystems to each other, the valuable services that ecosystems provide to humans, and the extent to which human activities that disrupt ecosystems can have ripple effects that extend over vast areas, it becomes more and more difficult to imagine any uses of land that do not entail some

sues connected with contamination by underground storage tanks or the health impacts of groundwater contamination, for example, may be quite complex and sophisticated.

161. See id. Demsetz makes the same mistake. See Demsetz, supra note 69, at 111-13. His analysis closely parallels Ellickson's. He begins by asserting that many externalities will be internalized within the boundaries of private property (what I call the "private property solution"). Id. at 111-12. He then acknowledges that some externalities will remain, but contends that these will usually impact only a small number of neighbors so that transaction costs will be low and Coasian bargaining feasible. Id. at 112-13. Like Ellickson, he asserts that most externalities will fall in one of these two categories. Id. at 113 ("The reduction in negotiating cost that accompanies the private right to exclude others allows most externalities to be internalized at rather low cost.") Finally, he acknowledges that some externalities will affect many people and that in such situations, high transaction costs will preclude Coasian bargaining, but he brushes these cases off as rare exceptions. Id. Indeed, this is a common tendency in the economics literature. Coase also confines his examples to medium rather than large events- the cattle trampling the neighbor's corn fields, the noisy confectioner disturbing the doctor, and so on. See Coase, supra note 34, at 2-10. Yet these examples have little relevance to the kinds of widespread health and ecological harms that dominate environmental law. See BROMLEY, supra note 28, at 51-54. 
significant "large events."162 Indeed, even the examples that Ellickson provides of small and medium events-"the planting and harvesting of crops, caring for children and animals, ... maintaining dwellings and other structures,"163 and the "construction of a small dam"164_are more appropriately categorized as large events if one understands the basic dynamics of ecological degradation.

For example, "the planting and harvesting of crops" involves choices about whether to use fertilizers and pesticides, which can have consequences for legions of people miles away who fish, swim, or withdraw drinking water from streams that are polluted by the runoff from the cultivated fields. If forests are cleared to plant crops, the impacts on biodiversity and global warming may be felt around the globe. If wetlands are filled to plant crops, the likelihood and severity of flooding throughout the region may be increased, as Hurricane Katrina all too vividly demonstrated. 165 Or migratory birds that are enjoyed by people on other continents, but that previously relied on that wetland as a source of food and shelter, may be harmed.

Indeed, it was "the planting of crops" that produced one of the "largest events" of ecological disaster in our nation's history-the Dust Bowl. During the early 1900s, across vast stretches of the American southwest, millions of individual farmers planted fields of wheat. This seemingly unremarkable land-use choice drastically altered the plains ecosystem, eliminating the diverse mix of drought-resistant grasses that had held the soil in place for millennia. ${ }^{166}$ When the inevitable drought cycle came in the 1930 s, the wheat died quickly, and,

162. Joseph L. Sax, Property Rights and the Economy of Nature: Understanding Lucas v. South Carolina Coastal Council, 45 STAN. L. REV. 1433, 1442-45 (1993); see Eric T. Freyfogle, Ownership and Ecology, 43 CASE W. RES. L. REV. $1269,1280,1288$ (1993) ("In our dealings with nature . . interconnection is the norm, not discreteness. . . No part of nature exists unattached and unaffected by the rest."). Much current land development activity produces myriad and wideranging externalities often denominated as urban or suburban sprawl. See William W. Buzbee, Urban Sprawl, Federalism and the Problem of Institutional Complexity, 68 FORDHAM L. REV. 57, 69-75 (1999).

163. See Ellickson, supra note 40, at 1329.

164. See id. at 1330 .

165. See Center for Progressive Reform, An Unnatrual Disaster: The Aftermath of Hurricane Katrina 10 (Sept. 2005), http://www.progressivereform.org/Unnat ural_Disaster_512.pdf.

166. DONALD WORSTER, DUST BOWL: THE SOUTHERn PLAINS IN THE 1930S, 6679, 83-97 (1979). 
with nothing to anchor it, the dry top soil was caught up in the fierce winds that rolled across the plains, creating severe dust storms that paralyzed the region for years, blackening skies, stinging eyes, clogging lungs, leaving the ground barren and lifeless, and driving millions from their homes. ${ }^{167}$ This event was so large that at one point it reached all the way across the continent, depositing a coating of dust in the corridors of the Capitol building in Washington, D.C. 168

Ellickson's other examples of small and medium events are just as problematic. Raising animals can pollute water supplies and degrade aquatic ecosystems. Raising children can put pressure on municipal services, like schools, fire, police, water, and sewer systems. Dwellings and other structures on land create impermeable surfaces which contribute to flash flooding and to the destruction of aquatic ecosystems as increased runoff from dozens of similar developments scours streambeds and erodes stream banks. Construction of even small dams blocks fish migration, alters stream flow and temperature regimes on which species depend, and generally wreaks havoc on aquatic ecosystems.

Indeed, some land uses are now understood to impose external effects that are literally global in scope. Any activity that involves combustion of carbon (the controlled burning of vegetation, for example) releases greenhouse gases into the atmosphere and, thus, exacerbates global warming. 169 Some agricultural processes release methane, a particularly potent greenhouse gas. And the clearing of vegetation also exacerbates global warming by diminishing carbon storage capacity. ${ }^{170}$

167. Id. at $10-25$.

168. Id. at 213.

169. See Intergovernmental Panel on Climate Change, Climate Change 2007: The Physical Science Basis, Summary for Policymakers 2, 5 (Feb. 2007), http:// www.ipcc.ch/SPM2feb07.pdf.

170. There is also the problem of temporal externalities-i.e., land use activities we engage in today that will impact future generations. Ellickson and the free market environmentalists claim that fee simple owners account for future harms and apply appropriate discount rates to incorporate the possibility of future harms into the present value of their land. See Ellickson, supra note 40, at 1369; see also ANDERSON \& LEAL supra note 7, at 40-43. But, that assumes that all future externalities are somehow internalized to future owners. It also assumes perfect information about the extent and nature of future impacts and that landowners will rationally discount future gains and losses. See FREYFOGLE, THE LAND WE SHARE, supra note 27, at 162-64; infra notes 176-181 and accompanying text; see also FREYFogle, Why CONSERVATION Is FAILING, supra note 3 , at 
Thus, in the real world, there are few land uses that produce only small or medium events. Yet, as Ellickson acknowledges, where large events occur, externalities are so large and wide-ranging that it is impossible to consolidate them within a single parcel. Where land use affects an ecosystem, for example, internalization of the relevant externality is likely to require consolidation of the entire ecosystem in a single owner.

But, ecosystems are not easily defined or delineated. They consist of vast networks of connections and dependencies between species, habitats, and geological formations. ${ }^{171}$ Imagine, for example, that we solve the monoculture problem posited in Part I.C.2.a ${ }^{172}$ by drawing a boundary around all of Garrett Hardin's original pasture and assigning ownership to one individual. What if a species of migratory bird that satisfies the preferences of bird watchers on another continent relies on the small reptiles and amphibians found in certain wetlands on the pasture as an essential food source on its annual migration? And what if the pounding of cattle's hooves through those wet areas in the pasture decimates the reptile and amphibian populations? Would it then be necessary for the pasture owner to expand her holdings to also include all the other areas across the globe that provide a habitat to this bird species on its annual migration?

Once one takes seriously the task of internalizing within property boundaries the myriad externalities caused by the vast network of ecosystem connections and interdependencies that criss-cross the landscape, the necessary parcels begin to appear unimaginably large. Ironically, as science continues to bring additional externalities to light, the private property solution necessitates ever larger parcels of land divided among fewer and fewer owners, and, thus, seems to work at crosspurposes with basic tenets of economic theory, which favor smaller parcels divided among many owners in order to pro-

48-50 (concluding that the duty to tend land in a way that respects and values future generations is fundamentally a communal ethical duty that cannot be fulfilled by the market).

171. See Robert Costanza \& Carl Folke, The Structure and Function of Ecological Systems in Relation to Property-Rights Regimes, in RIGHTS TO NATURE: EcoLOGICAL, ECONOMIC, CULTURAL, AND POLITICAL PRINCIPLES OF INSTITUTIONS FOR THE ENVIRONMENT 13, 13-18 (Susan S. Hanna, Carl Folke \& Karl-Göran Mäler eds., 1996).

172. See supra note 69 and accompanying text. 
mote a competitive market. ${ }^{173}$ Accordingly, the prevalence of large events makes the private property solution to the commons problems associated with land use untenable.

The prevalence of large events produced by land use activities makes the market solution untenable as well. A crucial component of the market solution to the tragedy of the commons is that all those affected by the externality be involved in the Coasian negotiation. But, where the numbers of people affected are large, transaction costs tend to be prohibitive. Even assuming all those affected can be accurately identified at a feasible cost, the collective action problems associated with such large groups are likely to be insurmountable. ${ }^{174}$ And where-as is often the case with environmental harms-each member of the group suffers some relatively minor, noneconomic injury, those problems are only exacerbated. ${ }^{175}$

Furthermore, regardless of whether land uses implicate

173. See BROMLEY, supra note 28 , at $60-61$ (noting the tension in market theory between consolidation to internalize externalities and extreme atomization to promote vigorous competition); see Demsetz, supra note 68, at 286-89 (suggesting consolidation of ownership of parcels of property as an alternative to Coasian bargaining in response to the externality problem).

174. See Ellickson, supra note 40, at 1334 ("[T] number coordinations might prevent the many [property owners affected by air pollution] from cooperating to resolve the dispute through some external institution.").

175. See George J. Stigler, Can Regulatory Agencies Protect the Consumer, in THE CITIZEN AND THE STATE: EsSAYS ON REGULATION 178, 186-87 (1975); George J. Stigler, The Theory of Economic Regulation, 2 BELL J. ECON. \& MGMT. SCI. 3, 11 (1971); see OLSON, supra note 84, at 16-23; see RUSSELL HARDIN, COLLECTIVE ACTION 101-08 (1982) (refining Olson's theory somewhat, explaining that despite collective-action problems, large groups $d o$ in fact organize to some extent, in part based on moral norms); see also Steven P. Croley, Theories of Regulation: Incorporating the Administrative Process, 98 CoLUM. L. REV. 1, 34-41 (1998) (summarizing the literature); Edward L. Rubin, Beyond Public Choice: Comprehensive Rationality in the Writing and Reading of Statutes, 66 N.Y.U. L. REV. 1, 12-13 (1991).

The transaction cost problem in part explains why so many environmental values are simply not reflected in markets. Thus, a scenic vista cannot be bought and sold on the market because the transaction costs associated with excluding people and then charging them for access are simply too large. Similarly, the existence value of a species cannot be captured by the market because the collective action problems associated with coordinating the large number of people who attach such value to a species are insurmountable. Of course, many people also argue that certain environmental values are not captured in markets because they are simply incommensurable with money. See, e.g., ANDERSON, supra note 26; Sunstein, supra note 26 , at $785-86$. These arguments challenge the fundamental assumptions of welfare economics and are therefore beyond the scope of this paper. 
small, medium, or large events, Ellickson's model also fails to account for the considerable extent to which inadequate information about ecological systems prevents landowners from making welfare-maximizing decisions regarding land use. When it comes to knowledge about ecological processes, informational problems are particularly unwieldy. The science of ecology is far from being able to provide detailed and accurate descriptions and predictions of ecosystem functioning. Indeed, ecologists are in some sense even further from that goal than they were (or perceived themselves to be) three decades ago. During the 1960s and 1970s, the science of ecology held out the promise that mathematical models would one day describe ecosystem functioning with Newtonian precision. In recent decades, however, it has become increasingly clear that ecosystems are mind-numbingly complex and chaotic. ${ }^{176}$ Because of this complexity, predicting how any particular disturbance will affect an ecosystem may often be impossible. ${ }^{177}$

Even where some meaningful prediction of the adverse effects of ecosystem disturbance is possible, it requires expensive scientific research. ${ }^{178}$ Yet, in a second tragedy of the commons-a tragedy of the informational commons-the actors responsible for negative ecosystem impacts face significant disincentives to produce such research. The benefits of the research fall primarily on others, while the costs fall mainly on the actor producing the ecosystem harm. The costs include not just the costs of the research itself, but the potential costs of increased regulation that may well result. Thus, information on the adverse ecosystem effects of land uses is a public good that is under-produced by the market. ${ }^{179}$

176. See DANIEl B. BOTKIN, DISCORDANT HARMONIES: A NEW ECOlOGY FOR THE TWENTY-FTRST CENTURY 9 (1990); Daniel A. Farber, Probabilities Behaving Badly: Complexity Theory and Environmental Uncertainty, 37 U.C. DAVIS L. REV. 145, 148-55 (2003); A. Dan Tarlock, The Nonequilibrium Paradigm in Ecology and the Partial Unraveling of Environmental Law, 27 LOY. L.A. L. REV. 1121, 1129 (1994).

177. See James Salzman, Valuing Ecosystem Services, 24 ECOLOGY L.Q. 887, 894 (1997) ("П]n most cases, our scientific knowledge is inadequate to predict with any certainty how specific local actions . . . will impact the local ecosystem services themselves. . . . [This is, in part, because] [a]nalysis of how ecosystems provide services has proceeded slowly because ecosystem level experiments are difficult, costly, and lengthy."); see also Harold Mooney \& Paul Ehrlich, Ecosystem Services: A Fragmentary History, in NATURE'S SERVICES 15-16 (Gretchen C. Daily ed., 1997).

178. See Salzman, supra note 177 , at 894 .

179. See Wagner, supra note 105, at 1625-59. 
These information problems lead not only to transaction costs that impede Coasian bargaining, but to distorted preferences-that is, preferences that do not actually track the overall, long-term well-being of individuals and which cause market efficiency to diverge from real social welfare. ${ }^{180}$ If, for example, market participants are ignorant of the valuable services that a given ecosystem provides, they may make choices in the market that lead to the ecosystem's degradation and thereby decrease real welfare (even while maximizing the satisfaction of their distorted preferences). ${ }^{181}$

In sum, while it is relatively easy to privatize land ownership because it is a resource that lends itself in physical terms to being divided into discrete, well-defined parcels, it does not follow that privatization necessarily solves the tragedy of the commons. Neither private ownership of land nor the existence of a market in land is alone sufficient to solve the tragedy. The specific criteria for either the private property or the market solution must be met. As the above discussion demonstrates, however, those criteria are likely to be met only rarely, if ever, in the context of land use.

\section{The Free-Market Environmentalists}

None of these difficulties have stopped the free market environmentalists from asserting that land privatization can solve the tragedy of the commons in all kinds of circumstances. Their argument essentially takes the following form: (1) where private property rights are well-defined, enforced, and transferable, the tragedy of the commons will be solved and the free

180. Matthew D. Adler \& Eric A. Posner, Rethinking Cost-Benefit Analysis, 109 YALE L. J. 165, 196-204 (1999); see Farber, supra note 29.

181. The problem of distorted preferences is arguably beyond the scope of this article since I promised at the outset to assume as true the assumption that willingness to pay (preference satisfaction) is a legitimate measure of social welfare. See supra notes 26-31 and accompanying text. Because information is often conceptualized as a transaction cost, however, I have chosen to address it. While on the subject, another reason to doubt the rationality of preferences regarding land use deserves mention, though it is technically outside the scope of this article. Behavioral research consistently shows that people apply irrationally high discount rates to risks of future loss, preferring to risk large future losses in order to avoid much smaller short term costs. See Thompson, supra note 8, at 262-65. This kind of cognitive bias may have played a significant role in driving the land use decisions that led to the Dust Bowl. See WoRSTER, supra note 166, at 26-43. 
market will produce efficient results; ${ }^{182}$ (2) property rights in land are easy to define and enforce; (3) therefore, all land should be privately owned (i.e., the federal public lands should be sold off to private interests), ${ }^{183}$ and, where land is privately owned, government regulation is unnecessary because we can rely on the market to produce economically efficient results. ${ }^{184}$

The first problem, of course, is that, as demonstrated above, well-defined, enforced, and transferable property rights do not in and of themselves necessarily lead to efficient results or a solution to the myriad commons problems that accompany various land uses. If externalities remain after the definition of property rights and transaction costs are too high to permit Coasian bargaining, the result may well be continuing tragedy. The free-marketeers essentially get around this problem by simply assuming away externalities and transaction costs. ${ }^{185}$

Thus, Anderson and Leal assume that the nineteenth century privatization of rangelands in the western United States solved the tragedy of the commons. ${ }^{186}$ But, they make no mention of the broader ecological impacts of cattle ranching-like the degradation of streams and fish habitats-that continue to impose extensive and wide-ranging external costs even after the privatization of rangelands. ${ }^{187}$ Nor do they mention the Dust Bowl, which followed one of the largest land privatization programs in American history. ${ }^{188}$

182. See, e.g., ANDERSON \& LEAL, supra note 7, at 22; see also Anderson et al., supra note 73, at 8; John Baden, Privatizing Wilderness Lands: The Political Economy of Harmony and Good Will, in PRIVATE RIGHTS \& PUBLIC LANDS, supra note 155 , at 53,54 .

183. The free market environmentalists-who, for reasons that are not entirely clear, seem to distrust state government less than they distrust federal government-focus their arguments for privatization on federal lands rather than on lands owned by state or local governments. See Anderson et al., supra note 73, at $1,14$.

184. Government ownership is, of course, simply a form of government regulation. See supra note 57 and accompanying text.

185. Michael Blumm, The Fallacies of Free Market Environmentalism, 15 HARV. J.L. \& PUB. POL'Y 371, 375-76 (1992).

186. ANDERSON \& LEAL, supra note 7, at 29-32.

187. See NELSON, supra note 155 , at 149.

188. See WORSTER, supra note 166 , at 82-89. After the federal government transferred millions of acres of public lands in the southwest plains to private hands, these new private land stewards were not driven by market incentives to maximize the long term value of their land. Quite the opposite occurred. In the early decades of the twentieth century, private landowners in the southwest pursued highly destructive and unsustainable land use practices that led to the massive ecological catastrophe of the 1930s dubbed the Dust Bowl. See id. 
Anderson and Leal even argue that the use of wasteful timber harvesting techniques by private landowners to clearcut the vast forests of the Great Lakes region in the late nineteenth century was actually economically efficient, given the abundance of timber and the scarcity of labor at that time and in light of trends in the supply of and demand for timber over time. ${ }^{189}$ Their argument assumes that only the values reflected in the market price of timber were relevant and, thus, entirely misses the point. They ignore all of the extensive and welldocumented externalities associated with timber harvest, from water quality degradation and fish habitat destruction to soil erosion and loss of species diversity. ${ }^{190}$

Indeed, as Anderson and Leal acknowledge, in one region-the Kingston Plains-clear-cutting at the turn of the century resulted in desertification so severe that the land has never recovered. ${ }^{191}$ Even here, they are unwilling to throw in the towel, insisting that that the private landowners' decisions to clear-cut this land "probably made very good economic sense,"192 though they offer no evidence to back up this claim.

To actually determine whether those decisions were economically efficient, one would need information on the value to society of the timber harvested as well as the value of the ecological services and environmental amenities foregone as a result of centuries of desertification. Lacking such evidence, Anderson and Leal instead resort to arithmetical cheap tricks.

189. ANDERSON \& LEAL, supra note 7, at 39-43; see also Gary D. Libecap, The Efficiency Case for the Assignment of Private Property Rights to Federal Lands, in PRIVATE RIGHTS AND PUBLIC LANDS, supra note 155, at 29, 32.

190. Anderson and Leal at one point make a half-hearted attempt to excuse their failure to consider non-market values with the admonition that "[w]e must keep in mind that decisions, whether in the private or the political sector, are always made in the context of contemporary values and information." ANDERSON \& LEAL, supra note 7 , at 44 . This argument is essentially circular, since imperfect information is, in fact, one of the transaction costs that causes the market to under-value and under-protect environmental amenities. Thus, the fact that the free market operates on the basis of imperfect information is precisely part of the problem. It is why the free market cannot be relied upon to provide sufficient levels of environmental protection. The insinuation that the information incorporated into market decisions will be just as faulty and incomplete as that incorporated into government decisions is simply false. There are many instances in which external effects that are well understood scientifically will be ignored by private market actors (because they are externalities), but will be taken into account, at least to some extent, by government regulators whose job is to assess and act on behalf of the public interest.

191. See ANDERSON \& LEAL, supra note 7, at 43.

192. Id. 
Using the magic of compounding interest, they convert the "value" of the timber harvested a hundred years ago to present dollars, in order to make it seem enormous. They roughly estimate the dollar value of the timber sold (based on the selling price of the land at the time) at $\$ 20$ per acre and then convert that to present dollars to get a "benefit" of $\$ 110,000$ per acre, or $\$ 2.8$ billion for the entire forty-square-mile $(25,600$-acre) tract. 193 They then rhetorically ask whether "the benefits derived over the past one hundred years from preserving land for wildlife habitat, hiking, and other environmental amenities [would] have been worth foregoing [those] benefits?"194 Apparently, they think not.

Although ecosystem values and services are extremely difficult to measure in dollar terms, in order to make a fair comparison, one would need to apply the same interest rate that Anderson and Leal applied to the value of the timber harvested to the value of the environmental amenities foregone. And, while the timber harvest produced just a one-time benefit, the environmental benefits would have accrued in each of the hundred years that have passed since the trees were cut. In fact, if we make the comparison fair in this way, it turns out that the value of the environmental amenities and ecosystem services destroyed by the clear-cutting would only need to amount to something more than $\$ 1.72$ per acre per year to render the clear-cutting decision economically inefficient. ${ }^{195}$ This estimate is actually far too high, since it fails to take into account the future period of environmental loss due to desertification, which even Anderson and Leal admit is likely to amount to centuries. ${ }^{196}$ It is certainly not hard to imagine that the annual environmental value of an acre of forest amounts to at least the value of a cup of coffee at Starbucks. ${ }^{197}$ But, by leaving their

193. See id. While Anderson and Leal do not reveal exactly what interest rate they used (or any other details of their calculation), their assertion that the $\$ 20$ per acre value would grow to $\$ 110,000$ over the course of one hundred years implies an interest rate of $8.61 \%$.

194. Id.

195. Let $\mathrm{V}=$ the total "benefit" per acre $(\$ 110,000)$. Let $p=$ the dollar amount per acre that the land in its natural state would have to "earn" each year in order to yield a total benefit of $V$. Let $t=$ time (from zero to 100 years). Let $a=$ the interest rate (here $0.0861 /$ year). Then: $V=\int_{0} 100$ pe $a(100 \cdot t) d t$. Solving for $p: p=$ $\mathrm{Va} /\left(\mathrm{e}^{100 \mathrm{a}}-1\right)=1.72$ dollars/year.

196. ANDERSON \& LEAL, supra note 7, at 43.

197. By one estimate, the benefits provided by an acre of forest in slowing global warming alone come to $\$ 36$ per year. See Robert Costanza et al., The Value 
calculation unfinished, Anderson and Leal conveniently avoid confronting numbers that do not support their blatantly endsdriven argument.

Another conceptual error that the free marketeers frequently commit is to assume that because the free market produces some conservation of land, it must be working. Thus, they repeatedly point to purchases of private lands for conservation by private individuals and groups like The Nature Conservancy, Audubon, and others as though it proves their case that the free market can solve the tragedy of the commons without government regulation. ${ }^{198}$ But, this argument erroneously conflates the amount of environmental protection that an imperfect market actually produces with the economically efficient amount. If there are negative environmental externalities or transaction costs that either prohibit landowners from internalizing the external effects of their land use or prevent them from negotiating with those harmed by the externalities-as there surely are-the result will not necessarily yield no land conservation. The result will simply be less land conservation than would otherwise occur in a perfect market. Since this is the problem, a showing that some land conservation has occurred does nothing to demonstrate that externalities or transaction costs have been eliminated or minimized, i.e., that the market "is working." Indeed, to the extent that externalities and/or transaction costs clearly persist, ${ }^{199}$ we can assume that the amount of conservation being produced by the

of the World's Ecosystem Services and Natural Capital, 387 NATURE 253, 256 (1997) (showing in table form the average annual value of climate regulation provided by one hectare of temperate forest to be eighty-eight dollars).

198. See, e.g., ANDERSON \& LEAL, supra note 7, at 4-5, 45, 69, 84-86, 172-74; Anderson et al., supra note 73, at 7; Terry L. Anderson, The Market Process and Environmental Amenities, in ECONOMICS AND THE ENVIRONMENT: A RECONCILIATION 137, 150-53 (Walter E. Block ed., 1990) [hereinafter Anderson, Market Process]; David Schmidtz, The Institution of Property, in Meiners \& Morriss, supra note 70 , at 109,115 .

199. In a perfect imaginary world with no transaction costs, we could count on groups like The Nature Conservancy to aggregate the preferences of all people for environmental protection and to purchase land and easements for conservation in economically efficient amounts. But, enormous transaction costs obviously make the real world far different. Groups like The Nature Conservancy face significant collective action problems. For example, people who have preferences for land conservation have incentives to free-ride on the contributions of others. See BROMLEY, supra note 28, at 36-38 (rebutting similar arguments: "[W] ho is to say that the Board of Directors of the Audubon Society speaks for the full citizenry in deciding what to purchase and to protect?'). 
market is in fact too low.

Based on arguments like these and a litany of anecdotes describing the incompetence and corruption of federal land managers, the free marketeers argue that all federal lands, including the national parks, should be sold off to private parties. ${ }^{200}$ Of course, as I have argued above, there is no reason to believe that private ownership in the absence of government regulation will solve the myriad commons problems associated with land use. While private ownership subject to regulation could conceivably provide an alternative to public ownership, this is decidedly not what the free market environmentalists are advocating. By failing to even specify which ideal privatization solution-private property or market-they think private ownership of federal lands can replicate and by failing to account for the numerous and wide-ranging externalities that accompany virtually all modern land use activities, the free marketeers fail to make a convincing case for selling off the federal lands.

\section{B. Privatizing the Oceans}

Innumerable commons tragedies occur in the oceans, from over-fishing to the destruction of marine ecosystems to pollution dumping. ${ }^{201}$ Indeed, a study published recently in the journal Science predicts that, if current trends continue, severe stresses on ocean ecosystems will cause every species of wildcaught seafood to collapse by the year 2050.202 Can privatization offer a solution to these tragedies? Again, answering this question requires consideration of the criteria developed in Part I for the private property and market solutions.

200. The arguments of the free market environmentalists rely heavily on the premise that government is inevitably incompetent and corrupt, but, while they acknowledge that the establishment of the institutions necessary for markets to function also requires an active government role, they do not explain why we should trust government to serve that function any better. See Krier, supra note 61 , at 341-42.

201. See Barton H. Thompson, Jr., Tragically Difficult: The Obstacles to Governing the Commons, 30 ENVTL. L. 241, 247-49 (2000) (citing ocean fisheries as a classic example of the tragedy of the commons).

202. Boris Worm, Impacts of Biodiversity Loss on Ecosystem Services, 314 SCI. 787-90 (Nov. 2, 2006). 


\section{The Myth}

First, consider how a private property solution to ocean commons problems might operate. At the outset, the definition and enforcement of boundaries in the ocean poses significantly greater challenges than on land. It is not so easy to build a fence in the ocean. ${ }^{203}$ But, technological solutions to this problem are at least conceivable. GPS technology, for example, might be used to delineate boundaries. If so, areas of ocean could perhaps be parceled out to individual property owners, much as on land. And, indeed, some free market environmentalists have proposed just such a system. ${ }^{204}$ Walter Block suggests that "[i]f people owned various patches of the ocean, they would have an economic incentive to protect their holdings ... [and] might well insist[, for example,] that any ship passing through their property with a cargo of oil be double-hulled." 205 Anderson and Leal suggest that "by specifying ownership of ocean surface area or of ocean floor, so-called territorial use rights in fisheries (TURFs)" could be used to solve commons problems arising with respect to fisheries, at least for species that are relatively non-mobile. ${ }^{206}$

As with land, of course, in order for such a parceling of the ocean to solve the commons problems associated with ocean re-

203. The free market environmentalists generally acknowledge that technological limitations can render private property rights impracticable where the technological means for definition and enforcement have not been developed. See, e.g., Adler, supra note 61 , at 14 . However, they are also optimistic about the potential for technology to overcome such problems over time. See, e.g., id. at 21.

204. See, e.g., Walter Block, Environmental Problems, Private Property Rights Solutions, in ECONOMICS AND THE ENVIRONMENT: A RECONCILIATION, supra note 191, at 292-93; BRUBAKER, supra note 90, at 213 ("Satellites make 'fencing' the ocean possible.").

205. Block, supra note 201, at 293.

206. ANDERSON \& LEAL, supra note 7, at 116. Katrina Wyman suggests that such privatization of the oceans is already happening: "[f]or over six decades, a movement has been underway around the world to enclose the oceans . . . similar to the famous enclosures of common lands in England ... . in the fifteenth century." Wyman, supra note 92, at 152. The two "waves" of enclosure that she contends have already occurred, however, both involve the assertion of government control rather than private property rights over ocean resources. She cites the post World War II assertion of jurisdiction by nations over the 200 -mile exclusive economic zones and the subdivision of nationally controlled fisheries into smaller units, like the eight regional fishery councils in the United States. Id. at 152-54. She identifies ITQs as the "third wave" of enclosure. Id. at 155-57. However, ITQs do not constitute privatization in the classic sense. See supra notes 96-109 and accompanying text. 
sources, all externalities arising from various uses of a given patch of ocean would need to be consolidated in an area with a size necessary to avoid the various commons problem. ${ }^{207}$ This arguably poses even greater challenges in the ocean than on land, since so many of the resources of value in the ocean are not fixed to the ocean floor the way a tree is to the earth, but are suspended in the water. Moreover, like land, oceans support myriad complex, wide-ranging, and overlapping ecosystems. In this environment, it is difficult to envision any delineation of property boundaries that would successfully eliminate spillover effects. ${ }^{208}$

Imagine, for example, that an owner of a parcel of ocean begins to catch fish from her parcel. While the effect might at first be small, even the removal of one fish will decrease other parcel owners' chances of catching fish from the same population. In order to eliminate all such externalities, a single parcel owner would need to own a large enough section of ocean to encompass an entire population of fish, and the population would have to be large enough to be genetically diverse and reproductively self-sustaining. If the fish species is one that is highly mobile and encompasses a large geographic range, then this would potentially require individual ownership of an enormous area of ocean. In any case, the parcel would inevitably include sections of habitat used by other species as well, which would create additional externalities with respect to those species, unless their entire ranges were also included in the original parcel. This might, in turn, overlap with still more species' habitats, and so on.

Moreover, even if the species harvested is not itself mobile and is located entirely within the boundaries of a relatively small patch of ocean, harvesting it may deplete the food source of other marine organisms found within and beyond the parcel's boundaries. Additionally, ocean water, like air, moves freely across boundaries, so that activities in one patch of ocean that alter water quality may well impact other areas. One owner might, for example, contract with someone to use her

207. See Adler, supra note 61 , at 20.

208. See Rieser, supra note 8 , at 418 ("[Because of] the increasing number of spillover effects between users [of marine resources] including fisheries bycatch levels, habitat destruction, and changes in biological relations among trophic levels (such as predator-prey relations) that now threaten the integrity of [the] whole marine ecosystem ... property rights [in marine resources] accorded any one individual cannot adequately take account of the entire ecosystem."). 
parcel for waste disposal or use her parcel of ocean for fish farming, which causes water pollution. 209 Because ocean currents transport sea water across vast distances, alterations in water quality in one part of the ocean may impact water quality in other regions as well.

As on land, then, there are so many wide-ranging and overlapping externalities associated with the use of ocean resources that a scheme of private property boundaries that successfully internalizes all of them is difficult, if not impossible, to imagine. Because the number of people using ocean resources has grown while the oceans remain finite and because our understanding of the complex network of interconnections between species and ecosystems has increased in recent years, individual users can no longer assume that their actions will not have external effects on others. In the words of fisheries scholar Alison Rieser, we have now "reach[ed] the end of the ocean-resource based frontier."210 In this new era, Rieser contends, we "must recognize that property rights accorded any one individual cannot adequately take account of the entire ecosystem. Nor can one individual acting alone, even when given incentives through a permanent property right, take sufficient action to ensure that all of the interconnecting components of a functioning ecosystem remain intact."211

As on land, the vast scope of so many of the externalities associated with the use of marine resources renders the market solution impracticable as well. Most uses of ocean resources are likely to involve at least some externalities that affect such large numbers of people as to render the collective action barriers to Coasian bargaining insurmountable. Moreover, additional barriers are posed by the lack of adequate information on marine ecosystem functioning and the considerable disincentives to the production of such information. ${ }^{212}$

\section{The Free Market Environmentalists}

The free market environmentalists are undaunted by these

209. For more information on how fish farming causes water pollution, see sources cited infra notes 214-19.

210. Rieser, supra note 8, at 418 (citing Susan Hanna, The New Frontier of American Fisheries Governance, 20 ECOLOGICAL ECON. 221 (1997)).

211. Id.

212. See Wagner, supra note 105 , at $1625-59$. 
difficulties. They contend that privatization solutions to ocean commons problems are tenable and that some are already operating successfully in practice. They point to privately owned oyster beds and fish farming as real-world examples. ${ }^{213}$ But, as in the context of land privatization, the free marketeers are able to make this argument only by assuming away certain externalities and associated transaction costs.

It is well-known that fish farming imposes significant and wide-ranging externalities on marine ecosystems. ${ }^{214}$ Large quantities of untreated fish waste released directly into the water, as well as the antibiotics and chemical pesticides often used by aquaculture operations, cause significant water pollu. tion problems. ${ }^{215}$ Indeed, some aquaculture operations are regulated under the Clean Water Act. ${ }^{216}$ The organic waste released into the ocean from salmon farms along the British Columbia coast is estimated to be equivalent to the raw human sewage from a city of $500,000.217$ Aquaculture also often introduces non-native species into new environments, disturbing ecosystems, spreading new diseases and parasites, and threatening biodiversity. ${ }^{218}$ The escape of farm-raised Atlantic

213. See, e.g., ANDERSON \& LEAL, supra note 7, at 116-19; MiCHAEL DE ALESSI, FISHING FOR SOLUTIONS 22-23, 53-57 (1998); Adler, supra note 61, at 1819; Terry L. Anderson \& Donald R. Leal, Fishing for Property Rights to Fish, in TAKING THE ENVIRONMENT SERIOUSLY 161, 166 (Roger E. Meiners \& Bruce Yandle eds., 1993) [hereinafter Anderson \& Leal, Fishing for Property Rights].

214. See generally Rosamond L. Naylor, Josh Eagle \& Whitney L. Smith, Salmon Aquaculture in the Pacific Northwest: A Global Industry, 45 ENV'T 18 (2003); Rebecca Goldburg \& Tracy Triplett, Environmental Defense Fund, Murky Waters: Environmental Effects of Aquaculture in the U.S. 35-48 (1997), http:/l www.environmentaldefense.org/documents/490_AQUA.pdf; Don Staniford, Sea Cage Fish Farming: An Evaluation of Environmental and Public Health Aspects (Oct. 1, 2002), http://www.eurocbc.org/Staniford_Flaws_SeaCage.pdf. (paper presented to European Parliament's Committee on Fisheries).

215. Naylor et al., supra note 214, at 31-32; Goldburg \& Triplett, supra note 214 , at $35-48$.

216. Effluent Limitations Guidelines and New Source Performance Standards for the Concentrated Aquatic Animal Point Source Category, 69 Fed. Reg. 51,891 (Aug. 23, 2004) (codified at 40 C.F.R. pt. 451).

217. Goldburg \& Triplett, supra note 214, at 38. A similar study in Scotland found that the waste from Scottish salmon farms was equivalent to the raw sewage discharge from nine million people. Malcom MacGarvin, World Wildlife Fund, Scotland's Secret: Aquaculture, Nutrient Pollution, Eutrophication, and Toxic Blooms 1 (Sept. 2000), http://www.wwf.org.uk/filelibrary/pdf/secret.pdf.

218. NAT'L RES. COUNCIL OF THE NAT'L ACADS., ATLANTIC SALMON IN MAINE 81-90 (2004) available at $\mathrm{http} / / / \mathrm{www}$.nap.edu/books/0309091357/html; Rosamund L. Naylor, Susan L. Williams \& Donald R. Strong, Aquaculture - A Gateway for Exotic Species, 294 SCI. 1655 (2001); Goldburg \& Triplett, supra note 214, at 49- 
salmon into the waters of the Pacific Northwest, for example, has caused substantial problems, as escaped salmon interbreed with wild salmon, spreading disease, compromising the genetic integrity and threatening the recovery of diminishing wild salmon stocks. ${ }^{219}$

With regard to oyster beds, the free market environmentalists point repeatedly to two studies performed by a pair of economists in the 1970s, indicating that privately owned oyster beds are more productive than government-managed beds. 220 But because both the public and private beds in the studies were subject to government regulation aimed at conserving the oyster populations by restricting harvesting techniques, ${ }^{221}$ these studies do not actually provide evidence that private ownership can replace government regulation as a solution to the tragedy of the commons. Furthermore, the onedimensional measure of success used in these studies-the level of oyster production-failed to account for the negative impacts on other elements of the ecosystem that might occur as a result of oyster farming. Certain harvesting techniques can damage the sea floor, disrupting the habitats of other species. Moreover, oyster farming has in some locales been responsible for the disruption of local ecosystems through the introduction of non-native oyster species and accompanying diseases and parasites. $^{222}$

On a somewhat grander scale, proposals have recently emerged to fertilize and harvest fish from large sections of open ocean. Michael Markels, Jr., founder of the company Ocean

57. Non-native species introduced by aquaculture include Japanese oysters farmed in the waters of the Pacific Northwest, Pacific white shrimp farmed along the Texas and South Carolina coasts, and African tilapia farmed throughout the United States. Goldburg \& Triplett, supra note 214, at 50-51.

219. Naylor et al., supra note 214, at 27-31. In 1996, approximately 100,000 Atlantic salmon escaped from salmon farms in Washington state. Goldburg \& Triplett, supra note 214 , at 10.

220. See ANDERSON \& LEAL, supra note 7, at 116; DE ALESSI, supra note 213, at 22; Adler, supra note 61, at 18-19; Anderson \& Leal, Fishing for Property Rights, supra note 213, at 166; Louis De Alessi, Gains from Private Property: The Empirical Evidence, in PROPERTY RIGHTS: COOPERATION, CONFLICT, AND LAW 90, 98-99 (Terry L. Anderson \& Fred S. McChesney eds., 2003). Each of these authors cite the same studies: Richard J. Agnello \& Lawrence P. Donnelley, Prices and Property Rights in the Fisheries, 42 S. ECON. J. 253 (1975) [hereinafter Agnello \& Donnelley, Fisheries]; Richard J. Agnello \& Lawrence P. Donnelley, Property Rights and Efficiency in the Oyster Industry, 18 J.L. \& ECON. 521 (1975).

221. Agnello \& Donnelley, Fisheries, supra note 220, at 258.

222. Naylor et al., supra note 214 , at 1655. 
Farming, Inc., argues that by fertilizing the gulf stream to stimulate the growth of phytoplankton, the productivity of the fisheries off the U.S. Atlantic coast could be increased by a factor of four hundred.223 Markels and other free market environmentalists argue that assigning private property rights to vast sections of ocean is necessary in order to create an incentive for individuals to engage in this kind of large-scale "ocean farming." Indeed, the Republic of the Marshall Islands has recently taken a step in that direction, signing an agreement with Ocean Farming, Inc., that gives the company the exclusive right to fertilize and harvest 800,000 square miles of open ocean in return for a royalty payment. ${ }^{224}$

But such property rights arrangements will not provide a solution to ocean commons problems. Oceanographers worry that Markels' ocean fertilization scheme could wreak ecological havoc. Enormous artificial algae blooms brought on by fertilization could have toxic effects, block light to species below the surface, and trigger the production of methane, a gas with a greenhouse impact thirty times that of carbon dioxide.225 Such impacts could easily reach well beyond the boundaries of any privately owned parcel of ocean and affect far too many people to allow market solutions to function.

\section{Fish and Wildlife}

Many of the externalities that plague attempts to privatize both land and ocean resources involve the over-exploitation of fish and wildlife. Indeed, because they move freely across property boundaries, fish and wildlife are, almost by definition, externalities. Thus, they provide classic textbook examples of the tragedy of the commons. ${ }^{226}$

A number of free market environmentalists have proposed

223. Michael Markels, Jr., Fishing for Markets: Regulation and Ocean Farming, 18:3 REG. 73 (1995).

224. ANDERSON \& LEAL, supra note 7, at 119; Michael Markels, Jr., Farming the Oceans: An Update, 21:2 REG. 9 (1998).

225. Charles Graeber, Dumping Iron, WIRED, Nov. 2000, at 170.

226. Two economists identified and described the tragedy of the commons in the context of fisheries in articles published over a decade before Garret Hardin's The Tragedy of the Commons, supra note 1. See supra note 35. Since then, the commons problems posed by fisheries have been extensively explored. See, e.g., Adler, supra note 61; Franz Thomas Litz, Harnessing Market Forces in Natural Resources Management: Lessons from the Surf Clam Fishery, 21 B.C. ENVTL. AFF. L. REV. 335, 336-39 (1994); Rieser, supra note 8, at 396-403. 
that these commons problems can be solved by privatizing the individual animals or organisms themselves. ${ }^{227}$ But, this approach confronts the same problems that make the privatization solution untenable in the context of land and oceans: numerous and wide-ranging externalities arising from the myriad connections and interdependencies between species and ecosystems.

\section{The Myth}

First, in order for the private property solution to work, a private owner of wildlife must own a large enough population to be genetically diverse and reproductively self-sustaining. Any smaller parcel of ownership would involve inevitable externalities. ${ }^{228}$ Furthermore, the owner of the wildlife also needs to control the other resources that make up the habitat on which that population depends. For certain species, this could require the control of vast tracts of territory. The territory for a male grizzly can be as large as 250 square kilometers. Moreover, an owner arguably needs to control not just the areas that the species itself occupies, but, also, the habitats of other species with which it is ecologically connected. This could include, for example, the habitat ranges of other species that are above or below the owned species on the food chain. As with the privatization of land and the oceans, once one considers the vast network of connections and interdependencies among species and ecosystems, any scheme for parceling out wildlife populations among private owners so as to eliminate or minimize externalities becomes virtually impossible to imag-

227. See, e.g., Anderson, Market Process, supra note 198, at 137, 147; Terry L. Anderson, Viewing Wildlife Through Coase-Colored Glasses, in WHO OWNS THE ENVIRONMENT? 259 (Peter J. Hill \& Roger E. Meiners eds., 1998) [hereinafter Anderson, Wildlife Through Coase]; Robert J. Smith, Resolving the Tragedy of the Commons by Creating Private Property Rights in Wildlife, 1 CATO J. 439, 443-44 (1981); Ike C. Sugg, To Save an Endangered Species, Own One, in ECOLOGY, LIBERTY, AND PROPERTY: A FrEe MARKET ENVIRONMENTAL READER 123 (Jonathan H. Adler ed., 2000); see also ANDERSON \& LEAL, supra note 7, at 121 (suggesting that technology allowing individual whales to be tagged and tracked could allow for private ownership of whales and free market solution to whale population declines); DE ALESSI, supra note 213, at 50 (same); Bruce Yandle \& Andrew P. Morriss, The Technologies of Property Rights: Choice Among Alternative Solutions to Tragedies of the Commons, 28 ECOLOGY L.Q. 123, 129 (2001) (same).

228. See supra notes 76-77 and accompanying text. 
ine. 229

Second, various externalities associated with wildlife ownership and management are likely to affect large and diffuse groups of people so that transaction costs and collective action problems would preclude Coasian bargaining in the real world. ${ }^{230}$ For example, one of the values frequently associated with wildlife is "existence value," the satisfaction that someone who will never actually see a particular animal derives simply from knowing that the species still survives in the wild. ${ }^{231}$ But those who derive existence value from a particular species of wildlife constitute a large and diffuse group, each member of which has a relatively small stake. This is exactly the type of group for whom collective action problems are most severe and insurmountable.

\section{The Free Market Environmentalists}

Undaunted by such difficulties, the free market environmentalists argue that private ownership of fish and wildlife can solve the commons problems associated with human exploitation. They cite game ranches, hunting preserves and safari parks as examples. ${ }^{232}$ Apparently regarding these enterprises as providing a market solution, they argue that safari and game park operators engage in a kind of Coasian bargaining with members of the public willing to pay money to hunt and

229. See Rieser, supra note 8 , at 418 . The free marketeers seem to recognize the problem in principle at times, but then point to a few anecdotes to defend their contention that it can be surmounted. See, e.g., ANDERSON \& LEAL, supra note 7 , at 63 ("[P]roducing a marketable product [in wildlife habitat] requires owning enough habitat to account for the migratory nature of wildlife and being able to charge demanders of the habitat for their enjoyment of it.").

230. Terry Anderson recognizes that this problem will at least occasionally preclude a market solution. See Anderson, Wildlife Through Coase, supra note 227, at 261 ("Wildlife and wildlife habitat will be underproduced through market processes if the contracting costs between the owners of wildlife and the owners of habitat prohibit exchange."). In response, he suggests "integration," where all interacting wildlife and habitat are owned by a single firm. See id. at 264. This is essentially the private property solution, but he glosses over the considerable problems posed by wide-ranging and overlapping habitats, see supra notes 171-72 and accompanying text, and fails to acknowledge that such consolidation will tend to undermine the competitiveness of the market, see supra note 173 and accompanying text.

231. Thomas H. Stevens et al., Measuring the Existence Value of Wildlife: What Do CVM Estimates Really Show?, 67 LAND ECON. 390 (1991).

232. See ANDERSON \& LEAL, supra note 7, at 66-69; Anderson, Wildlife Through Coase, supra note 227, at 267-68; Smith, supra note 227, at 453. 
view wildlife in their parks. The collection of fees from these visitors creates an incentive on the part of the business owners to protect and conserve the "wild" life they own. While it may have some superficial appeal, this reasoning is hopelessly flawed. Game parks and safaris may offer an example of the operation of a certain type of economic incentive, but they hardly involve Coasian bargaining.

Here, the free marketeers make the same mistake they make in discussing the private land conservation efforts of groups like The Nature Conservancy. They erroneously assume that because the free market has produced some wildlife, it has produced the economically efficient (or welfare maximizing) amount. They also make the unsupportable assumption that the type of wildlife produced by the market- "wild" animals in captivity-is the type of wildlife that would be preserved if the preferences of all people affected by wildlife conservation efforts were, in fact, taken into account.

True Coasian bargaining that leads to an economically efficient or socially optimal amount of wildlife conservation requires that transaction costs be zero (or at least de minimus). But, in the real world, the transaction costs associated with wildlife conservation are clearly significant. First, there are many others besides those who pay to go to game parks and safaris who are either benefited or harmed by such places but are not involved in "negotiations" - those who may never see the wildlife, but, nonetheless, attach an "existence value" to it; those who would have derived benefits had the land devoted to the safari park been left in its natural state without the introduction of exotic species; those who derive pleasure from watching migratory birds that use habitat preserved for the game park as a rest stop on their annual migration; those who benefit from the water resources that are kept clean because the forest through which certain streams flow is kept intact in order to support the wildlife at the game park; and so on.

This list could obviously go on and on. The point is that the group of people who derive benefit from the conservation of a particular species of wildlife or its habitat is far larger and more diverse than the group of people willing to pay to visit a game park or safari. Transaction costs prevent all those affected by the decisions made by owners of wildlife from being involved in the negotiation, but, if they were, the outcome of the negotiations would undoubtedly be quite different. More 
money might be offered for the preservation of wildlife and more natural habitat protected.

Additionally, all wildlife habitat is not fungible. If people other than hunters were also at the "negotiating table" with the owners of a hunting preserve, the land might be managed quite differently so that it supported a different mix of species. Clear-cutting, for example, can increase habitat for deer (valuable to hunters), while destroying the value of the forest for people who derive aesthetic or spiritual satisfaction from it and for old-growth dependent species like the spotted owl. Finally, imperfect information-the fact that many people are unaware of the full benefits to be gained from wildlife conservation-will also cause real-world bargaining to under-produce wildlife conservation. ${ }^{233}$

Another example of a privatization solution to wildlife commons problems repeatedly cited by the free market environmentalists is the program operated by Defenders of Wildlife, which pays compensation to ranchers in the western U.S. who lose livestock due to the U.S. Fish and Wildlife Service's wolf reintroduction program. ${ }^{234}$ Through donations from individuals and foundations, Defenders has set up a fund that it uses to compensate ranchers who lose livestock to wolf attacks. 235 But, this is not an example of true Coasian bargaining either. True Coasian bargaining would provide an answer to the "how much" question-in this instance, it would determine the number of wolves to be reintroduced. That number would be a function of how much those benefited by wolf reintroduction were willing to pay and how much those harmed by wolf reintroduction were willing to accept. ${ }^{236}$ In this situation, however, the number of wolves to be reintroduced has already been determined by government decree. The Defenders program comes into play later to provide compensation to those harmed, but it does not determine the level of harm. Thus, it redistributes wealth rather than answering the "how much" question.

Even if the government were to hand over the "how much"

233. See supra notes 176-81 and accompanying text.

234. See, e.g., Anderson, Wildlife Through Coase, supra note 227, at 266-67.

235. Defenders of Wildlife, The Bailey Wildlife Foundation Wolf Compensation Trust, http://www.defenders.org/wolfcomp.html (last visited Feb. 3, 2007).

236. Alternatively, if the law provided an entitlement to wolf reintroduction, the negotiation would involve the ranchers' willingness to pay and the conservationists' willingness to accept. 
question to a negotiation between Defenders and the ranchers, it would not produce an optimal Coasian solution because, as in the many other situations discussed above, innumerable transaction costs would grossly distort the outcome. Defenders provides a wildly imperfect proxy for the large and heterogeneous group of people benefited by wolf conservation. The amount of money the group would be "willing to pay" in the negotiation would depend on how much money they could raise from voluntary contributions. But, basic principles of interest-group theory tell us that many of those benefited by wolf reintroduction would free-ride on the contributions of others and that the funds raised by Defenders would accordingly be less than the actual aggregate willingness to pay of those who stand to benefit. ${ }^{237}$

\section{CONCLUSION}

In innumerable iterations throughout the economy, the tragedy of the commons threatens to make us get the "how much" question wrong-to release too much pollution into the air and water, to cut too many trees from the forest, to catch too many fish from the sea. Decades ago, in a less cynical era, we turned to government to solve the tragedy. But, in recent years, as the self-interested economic man has gradually come to replace the virtuous public-regarding citizen in our vision of ourselves and our society, intellectual fashions have come to favor Garrett Hardin's other solution-the privatization of the commons.

Yet, if we look closely at those schemes that are most often touted as examples of the privatization solution, it becomes apparent that, in fact, they are no such thing. Some create market-like institutions but continue to leave the crucial "how much" question to government and are, therefore, more appropriately categorized as forms of government regulation. Others do leave the "how much" question to the private market, but are only capable of delivering a reasonably accurate answer in a perfect world of frictionless interactions and discrete containable impacts that exists only in theory. They fail to even provide a mechanism for taking into account the innumerable wide-ranging externalities that accompany so much of human

237. See OLSON, supra note 84, at 16-23. 
activity in the real world and that so often drive commons problems to begin with.

On some level, this is simply a problem of labels. But labels matter. Language shapes thought. And mischaracterizing ETMs as examples of the successful implementation of the privatization solution to the tragedy of the commons only lends credence to the preposterous claim that, in dealing with environmental problems, government regulation can be entirely dispensed with and replaced by a regime of private property rights.

Free market environmentalists will no doubt respond that even if private property and market regimes suffer imperfections due to externalities and transaction costs, the imperfections of government regulation are far worse. In their view, the inevitably skewed incentives faced by government officials lead inexorably to widespread corruption and mismanagement and render government regulation far more harmful than helpful. But, such protestations are beside the point. It has not been my project here to argue that government regulation will always offer a perfectly calibrated solution to the tragedy of the commons.

Clearly, government regulation suffers many failures of its own. 238 Designing a government regulation solution becomes particularly challenging in the context of the oceans, for example, where no single jurisdiction exercises sovereignty over the resources at issue. ${ }^{239}$ Additionally, the enormous scientific uncertainties associated with ecological externalities present formidable informational hurdles for governments as well as markets. ${ }^{240}$ But, too often, the debate proceeds based on blithe references to the "privatization solution" to the tragedy of the commons, as though any delineation of private property rights will automatically "solve" the problem. Those who promote privatization solutions should instead be forced to go through the paces of demonstrating exactly how their proposed privatization schemes will actually operate to solve commons problems. Such a demonstration will inevitably reveal that, where externalities are wide-ranging (as they so often are), private property and market regimes in fact utterly fail to provide a so.

238. See, e.g., Thompson, supra note 201, at 255-65.

239. See William W. Buzbee, Recognizing the Regulatory Commons: A Theory of Regulatory Gaps, 89 IOWA L. REV. 1, 25 (2003).

240. See supra notes $176-81$ and accompanying text. 
lution. I hope the preceding pages have demonstrated that this failure stems not simply from some minor slippage or noise in the translation from theory to practice, but, rather, from a complete failure to even begin to account for the very externalities that drive commons problems. While government regulation may have many failings, it at least provides a mechanism for attempting to take wide-ranging externalities into account.

Moreover, government regulation is not a monolith, but comes in many forms, each of which may be more or less effective depending on the context in which it is deployed. Any thoughtful evaluation of the effectiveness of government regulation must avoid generalizations and give separate consideration to different methods of regulation, paying close attention to how they actually operate in particular contexts. Finally, as many before me have observed, even the private property and market regimes that the free marketeers advocate require a substantial role for government in defining and enforcing property rights. It is not clear why we should expect government to fail so miserably in administering traditional forms of regulation but not in setting caps for ETMs or defining and enforcing private property rights.

Finally, it bears repeating that my point has not been to say that private property regimes and markets are bad ideas. These institutions often have a valuable and important role to play in social organization. ${ }^{241} \mathrm{My}$ point is, rather, to make clear that private property regimes and markets rarely, if ever, provide real-world solutions to the tragedy of the commons in the absence of government regulation. In some instanceswith respect to land, for example-private property regimes may simply need to be accompanied by a system of government regulation in order to address the numerous commons problems left unresolved by the market. In other instances, the institutions we call "markets"-ETMs and water markets, for example-are themselves simply forms of government regulation. And recognizing them as such is essential to thinking clearly and accurately about the roles of governments and markets in society.

241. See Byrne, supra note 61 , at $679-80$. 